\title{
Interspecies Jumping of Bat Coronaviruses
}

\author{
Antonio C. P. Wong (D), Susanna K. P. Lau*(D) and Patrick C. Y. Woo*(D) \\ Department of Microbiology, Li Ka Shing Faculty of Medicine, The University of Hong Kong, Pokfulam, \\ Hong Kong, China; antonwcp@connect.hku.hk \\ * Correspondence: skplau@hku.hk (S.K.P.L.); pcywoo@hku.hk (P.C.Y.W.)
}

Citation: Wong, A.C.P.; Lau, S.K.P.; Woo, P.C.Y. Interspecies Jumping of Bat Coronaviruses. Viruses 2021, 13, 2188. https://doi.org/10.3390/ v13112188

Academic Editors: Peng Zhou and Danielle E. Anderson

Received: 11 October 2021

Accepted: 28 October 2021

Published: 29 October 2021

Publisher's Note: MDPI stays neutral with regard to jurisdictional claims in published maps and institutional affiliations.

Copyright: (c) 2021 by the authors. Licensee MDPI, Basel, Switzerland. This article is an open access article distributed under the terms and conditions of the Creative Commons Attribution (CC BY) license (https:// creativecommons.org/licenses/by/ $4.0 /)$.

\begin{abstract}
In the last two decades, several coronavirus (CoV) interspecies jumping events have occurred between bats and other animals/humans, leading to major epidemics/pandemics and high fatalities. The SARS epidemic in 2002/2003 had a 10\% fatality. The discovery of SARS-related CoVs in horseshoe bats and civets and genomic studies have confirmed bat-to-civet-to-human transmission. The MERS epidemic that emerged in 2012 had a 35\% mortality, with dromedaries as the reservoir. Although CoVs with the same genome organization (e.g., Tylonycteris BatCoV HKU4 and Pipistrellus BatCoV HKU5) were also detected in bats, there is still a phylogenetic gap between these bat CoVs and MERS-CoV. In 2016, 10 years after the discovery of Rhinolophus BatCoV HKU2 in Chinese horseshoe bats, fatal swine disease outbreaks caused by this virus were reported in southern China. In late 2019, an outbreak of pneumonia emerged in Wuhan, China, and rapidly spread globally, leading to $>4,000,000$ fatalities so far. Although the genome of SARS-CoV-2 is highly similar to that of SARS-CoV, patient zero and the original source of the pandemic are still unknown. To protect humans from future public health threats, measures should be taken to monitor and reduce the chance of interspecies jumping events, either occurring naturally or through recombineering experiments.
\end{abstract}

Keywords: interspecies jumping; bat; coronavirus; outbreak; epidemic; pandemic; SARS; MERS; SADS; COVID-19

\section{Introduction}

Coronaviruses (CoVs) are positive-sense, single-stranded RNA viruses that infect mammals and birds. CoVs are classified into four genera, Alphacoronavirus (previously group $1 \mathrm{CoV}$ ), Betacoronavirus (previously group $2 \mathrm{CoV}$ ), Gammacoronavirus (previously group $3 \mathrm{CoV}$ ) and Deltacoronavirus, of which Betacoronavirus is subclassifed into five subgenera, namely Embecovirus (the traditional betaCoVs), Sarbecovirus, Merbecovirus, Nobecovirus and Hibecovirus. From our present knowledge, bats are the hosts of only Alphacoronavirus and the subgenera Sarbecovirus, Merbecovirus and Nobecovirus of Betacoronavirus [1]. The size of a $\mathrm{CoV}$ varies from $26 \mathrm{~kb}$ to $31 \mathrm{~kb}$ [2]. Around two-third of the genome is occupied by open reading frame $1 \mathrm{ab}(\mathrm{ORF} 1 \mathrm{ab})$, which encodes 15-16 non-structural proteins (nsps), including papain-like protease, chymotrypsin-like protease, RNA-dependent RNA polymerase (RdRp), helicase, etc. [3]. The remaining one-third of the genome encodes the spike $(\mathrm{S})$, envelope $(\mathrm{E})$, membrane $(\mathrm{M})$ and nucleocapsid $(\mathrm{N})$ proteins $[3,4]$. Furthermore, a variable number of additional accessory genes that code for accessory proteins may also be present downstream to ORF1ab. These accessory proteins do not display significant homologies to those from other more distantly related CoV species [5]. Mutations, insertions and deletions are common in these accessory genes [6-9]. Although the accessory proteins are generally considered non-essential for viral replication, most of their functions are not fully understood [10-16].

The first step of interspecies jumping requires binding of a $\mathrm{CoV}$ to the cells of a new host [17]. The virus is then internalized and if it can utilize the machinery of the new host for replication, it may be able to perpetuate in the host [18]. Further adaptation usually requires additional mutations in the viral genome [19]. The $S$ protein is located on the surface of the 
virus. During an infection, it binds to the receptor of the host, resulting in virus entry [20]. Therefore, it is undeniably the most crucial protein that determines whether a particular $\mathrm{CoV}$ can infect a specific host, and mutations in the $S$ gene, either naturally or through recombineering experiments, may lead to potential interspecies jumping [21-27]. The $S$ protein consists of two parts, S1 and S2. S1 is the longer (but more variable in length e.g., $\sim 685$ amino acids in SARS-CoV and $~ 750$ amino acids in MERS-CoV) and exposed part that contains the receptor binding domain (RBD), whereas S2 ( 600 amino acids) is the shorter and more conserved transmembrane portion [28-30]. In some CoVs, the $\mathrm{S}$ protein is cleaved at the S1/S2 junction and modification of the amino acids at the cleavage site would affect the infectivity of the virus [31]. In addition to the $S$ protein, other accessory proteins may also play important roles in subsequent adaptation to the new host after interspecies jumping [9,11,32-34].

In this article, we review the probable $\mathrm{CoV}$ interspecies jumping events that are known to have occurred between bats and other animals/humans, most of which have resulted in major epidemics and pandemics and frighteningly high fatalities. Transmission and adaptation of CoVs between different bat species, such as the jumping of Bat coronavirus HKU10 between Leschenault's rousettes (Rousettus leschenaulti) and Pomona leaf-nosed bats (Hipposideros Pomona), will not be included [35].

\section{SARS-CoV: The Classical Example of Bat-To-Animal-To-Human Interspecies Jumping}

The SARS epidemic in 2002/2003 had a fatality of around 10\% among the 8000 laboratory confirmed cases [36]. Patient zero of the epidemic was believed to be a cook who had handled animals in a restaurant in southern China that served meat from wildlife [37]. After circulating in mainland China for a few months, it was transmitted to Hong Kong in early 2003 by a Chinese professor who stayed in a hotel in Hong Kong, a busy international financial hub and the gateway of China [38-40]. During the same visit, the Chinese professor has also infected other residents in the hotel, who efficiently spread the infection from Hong Kong to different parts of the world when they went back to their corresponding home countries [39,41].

Shortly after the isolation of SARS-CoV, the virus was discovered in palm civets in wet markets in the Guangdong Province [8]. However, multiple lines of evidence showed that the civets were probably just the intermediate hosts, but not the ultimate ancestor of SARS-CoV (Figure 1) [42-44]. One part of the evidence was that only civets in the farms, but not those in the wild, were found to harbor the virus, indicating that the civets had only acquired the virus recently, instead of being its reservoir for a long time (Figure 1) [42] Intensive surveillance research in Hong Kong was therefore carried out and revealed that SARSr-CoVs were present in the fecal samples of Chinese horseshoe bats (Rhinolophus sinicus) that resided in caves and water tunnels in Hong Kong [45]. Other studies in China have also found these SARSr-CoVs in different horseshoe bat species, including greater horseshoe bats (Rhinolophus ferrumequinum), big-eared horseshoe bats (Rhinolophus macrotis), least horseshoe bats (Rhinolophus pusillus), intermediate horseshoe bats (Rhinolophus affinis), and Blasius's horseshoe bats (Rhinolophus blasii), as well as Stoliczka's Asian trident bats (Aselliscus stoliczkanus) and wrinkled-lipped free-tailed bats (Chaerephon plicata), mainly in various provinces in southern China but occasionally in other countries [17,33,46-49]. Interestingly, for reasons not fully understood, there have been no more human SARS cases since July 2003, except for a number of laboratory acquired cases in China in late 2003 to early 2004 [50]. 


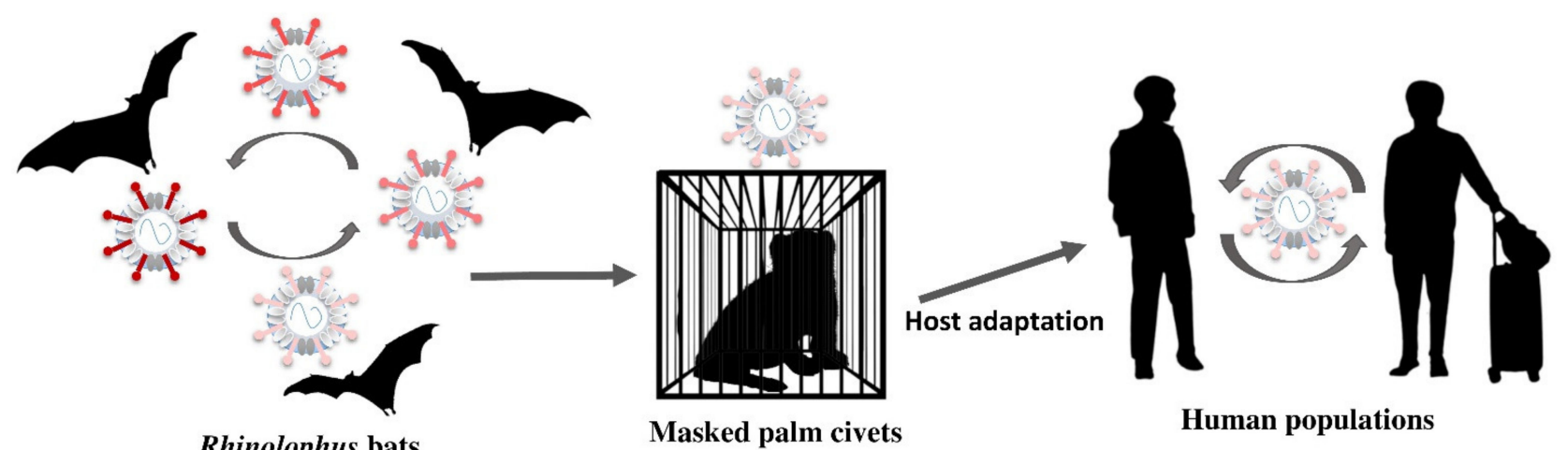

Rhinolophus bats

Masked palm civets

Human populations

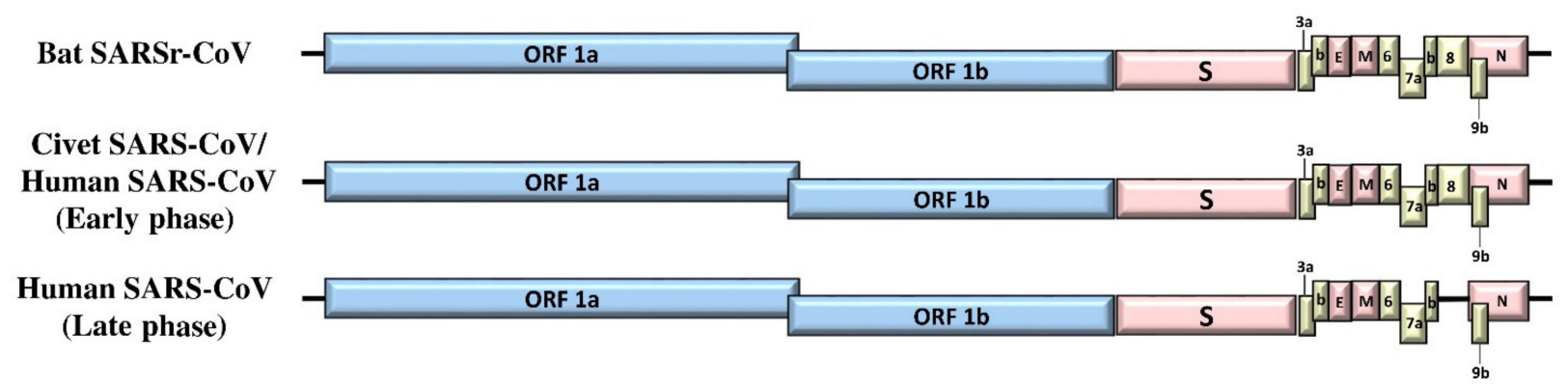

Figure 1. Overview of interspecies transmission events of SARS epidemic in 2003 and genome organizations of SARSr-CoV from different hosts. Arrows indicate the direction of viral interspecies jumping and viral molecular evolution between different host species. Circular arrows indicate the circulation of virus within the population. ORF1a and ORF1b are represented by blue boxes, structural proteins by pink boxes, and accessory proteins by yellow boxes.

SARSr-CoVs from humans, civets and bats belong to the subgenus Sarbecovirus of Betacoronavirus. The size of their genomes is around $29,750 \mathrm{bp}$. In addition to the basic genome backbone 5'-ORF1ab-S-E-M-N-3', several ORFs that encode accessory proteins, including ORF3a, ORF3b, ORF6, ORF7a, ORF7b, ORF8 and ORF9b, are present (Figure 1 and Table 1) [51]. Among the proteins, the $S$ protein is the most crucial in dictating the interspecies jumping. The receptor for SARS-CoV in humans is angiotensin-converting enzyme 2 (ACE2) $[29,52,53]$. Not unexpectedly, the $S$ proteins from most SARSr-CoV strains found in the horseshoe bats were not able to bind the ACE2 in humans [45,54]. However, it was shown recently that the $S$ proteins of some SARSr-CoV strains found in bats from the Yunnan province in China were able to bind the ACE2 in humans, suggesting that this was an important step in the evolution of the virus towards jumping to humans [24-26]. Since the $S$ protein is so crucial in determining infection across difference animal species, two groups have performed recombineering experiments involving the $S$ protein to ascertain its importance. Since the SARS epidemic, a large diversity of bat SARSr-CoVs has been found in various species of horseshoe bats, with complete genome sequences available, facilitating such experiments (Figure 2). One of the bat SARSr-CoV strains, named WIV1, successfully isolated in Vero E6 cells by a group of Chinese scientists in Wuhan in 2013, was shown to be able to utilize the ACE2 receptors of humans, civets and Chinese horseshoe bats for host cell entry, implying its potential to have broad species tropism [26]. In 2015, another group, in the USA, extended the study of potential interspecies transmission by developing a reverse genetics system for generating chimeric SARSr-CoV [25]. They cloned the $S$ gene obtained from bat SARSr-CoV strain SHC014, predicting that its S protein could bind ACE2 as do those SARSr-CoV strains that possessed similar $\mathrm{S}$ protein sequences with the critical amino acid residues for ACE2-binding, to a mouse-adapted SARSr-CoV strain MA15 backbone. The recombinant SARSr-CoV strain SHC014-MA15 was able to multiply in mouse DBT cell lines expressing human, civet or bat ACE2, indicating that the $S$ protein of bat SARSr-CoV strain SHC014 was able to utilize different orthologs of human ACE2 as receptors. Furthermore, the recombinant SARSr-CoV strain SHC014-MA15, but not the original SARSr-CoV strain SHC014, was also able to infect BALB/c mice with 
substantial weight loss observed, suggesting the potential of interspecies transmission of the recombinant virus in laboratory settings. After this initial success, the research group further generated another chimeric SARSr-CoV by cloning the $S$ gene of SARSr-CoV strain WIV1 into the mouse-adapted SARSr-CoV strain MA15 backbone and rescued in Vero cells. Animal experiments suggested that both the SARSr-CoV strain WIV1 and the recombinant SARSr-CoV strain WIV1-MA15 could not significantly infect BALB/c mice [24]. However, they showed subsequently that the SARSr-CoV strain WIV1 was able to cause attenuated infection in transgenic mice expressing human ACE2, indicating that the species barrier could be overcome by altering the target host cellular expression profile genetically.

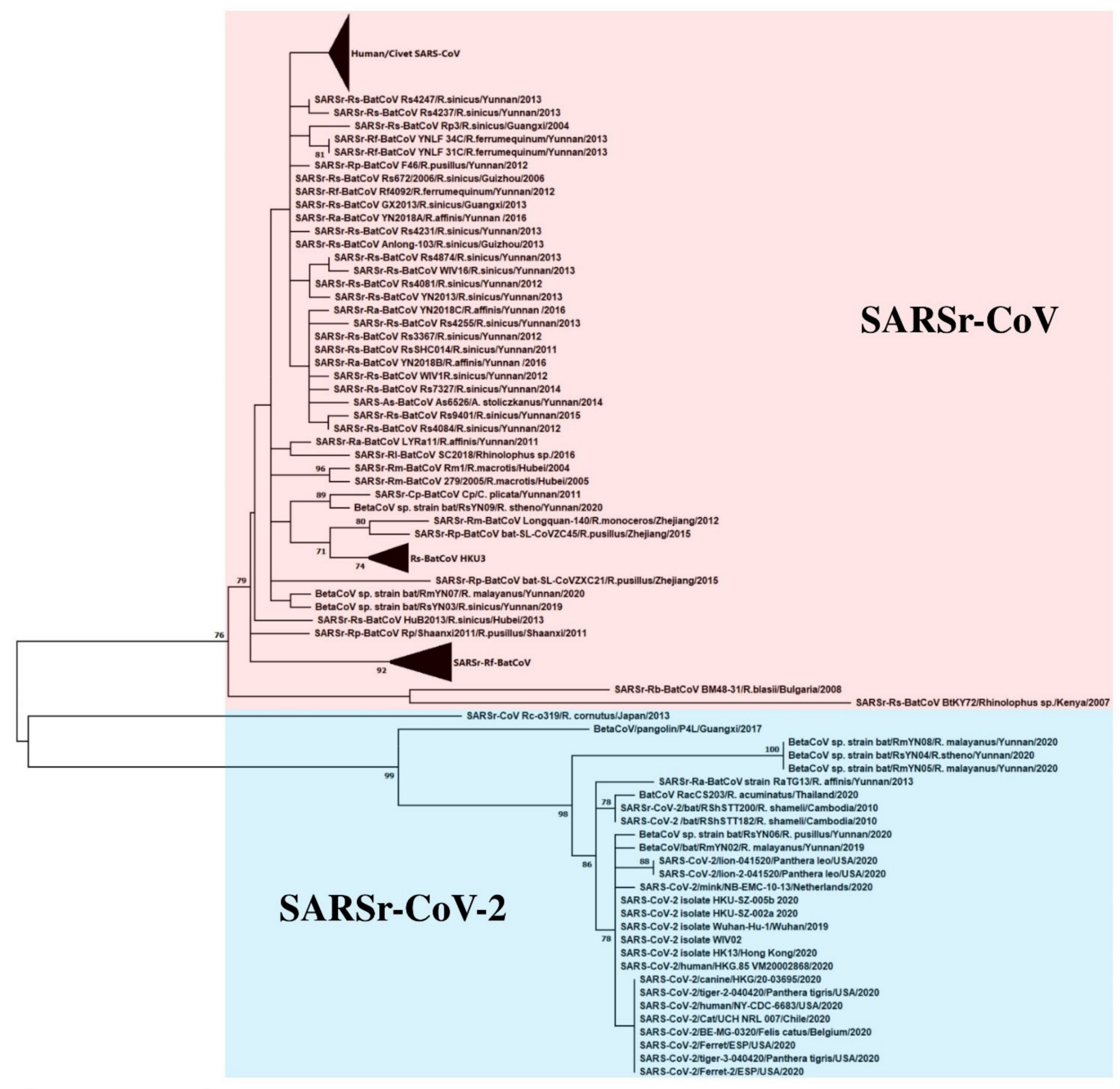

0.01

Figure 2. Maximum-likelihood phylogeny based on the nsp12 amino acid sequences of selected SARSr-CoVs. A JonesTaylor-Thornton (JTT) model of amino acid substitution was used in the analysis with a discrete gamma $(\gamma)$ distribution and the assumption that a certain fraction of sites is evolutionarily invariable (+I). 1000 trees were set for bootstrap values calculation. All bootstrap values and the scale bar indicating the number of amino acid substitutions per site are shown. Viral strains highlighted in red color represents the SARSr-CoV cluster; blue color represents the SARSr-CoV-2 cluster. 
Table 1. Putative functions of SARS-CoV accessory proteins.

\begin{tabular}{|c|c|}
\hline Accessory Protein & Putative Function(s) \\
\hline ORF3a & $\begin{array}{l}\text { Induces chemokines production, including RANTES and IL-8; activates } \\
\text { NF- } \mathrm{kB} \text { and JNK [55] }\end{array}$ \\
\hline ORF3b & $\begin{array}{c}\text { Induces necrosis or apoptosis; } \\
\text { upregulates cytokines through RUNX1 [56] }\end{array}$ \\
\hline ORF6 & $\begin{array}{l}\text { Formation of double membrane vesicles [57]; } \\
\text { inhibits nuclear import of STAT1 (IFN- } \beta \text { antagonist) [58] }\end{array}$ \\
\hline ORF7a & $\begin{array}{l}\text { Activates NF-kB and JNK [55]; } \\
\text { induces apoptosis; } \\
\text { inhibits host protein translation; } \\
\text { activates p38 MAPK [59] }\end{array}$ \\
\hline ORF7b & Remain to be elucidated \\
\hline ORF8 & Activates ATF6; upregulates ER-resident chaperons [60] \\
\hline ORF9b & Suppresses IFN responses by indirectly degrading MAVS [61] \\
\hline
\end{tabular}

RANTES: regulated on activation, normal T cell expressed and secreted; IL-8: interleukin-8; NF-kB: nuclear factor kappa-light-chain-enhancer of activated B cells; JNK: c-Jun N-terminal kinases; RUNX1: runt-related transcription factor 1; STAT1: signal transducer and activator of transcription 1; MAPK: mitogen-activated protein kinase; ATF6: activate activating transcription factor 6; ER: endoplasmic reticulum; IFN: interferon; MAVS: mitochondrial antiviral-signaling protein.

\section{MERS-CoV: Is It from Bat Again?}

Bats were not known to be hosts for CoVs before SARS. After the SARS epidemic and the discovery that bats are the ancestor of SARSr-CoVs, at least 17 novel CoVs have been found in various species of bats [17,62-64]. In additional to the discovery of these previously unknown bat CoVs, between the SARS outbreak in 2002/2003 and the emergence of MERS in 2012, there have been many other advances in our knowledge and understanding in CoV diversity and phylogeny [62-64]. A fourth genus of CoV, Deltacoronavirus, has been discovered, in addition to the three genera, Alphacoronavirus, Betacoronavirus and Gammacoronavirus that have been known for decades [65-68]. Betacoronavirus was also subclassified into the four subgenera Embecovirus (the traditional betaCoVs), Sarbecovirus, Merbecovirus and Nobecovirus during this period [64].

The MERS epidemic that emerged in 2012 had a frightening mortality of around 35\% among the laboratory confirmed cases. Patient zero was a 60-year-old Saudi Arabian male from Jeddah in Saudi Arabia, from whom the first MERS-CoV strain, that belonged to the subgenus Merbecovirus in Betacoronavirus, was isolated [69,70]. Although the total number of laboratory-confirmed cases so far is only around 2500, the epidemic is still ongoing. Patients who developed MERS were either from the Middle East or had recently travelled there or were in contact with returning travelers from the Middle East. So far, the largest cluster of cases was in Saudi Arabia, involving over 600 patients; whereas outside the Middle East, the largest cluster occurred in South Korea, which originated from a patient who visited the Middle East and brought the infection back to his home country, infecting a total of 184 patients [71-73].

Shortly after the emergence of the MERS epidemic in humans, intensive surveillance studies have found that MERS-CoV was present in the respiratory samples of dromedaries in the Middle East and North Africa, suggesting that it was the reservoir of the virus (Figure 3) [74-76]. Infection was acquired through direct or indirect contact with the camels [77]. Further studies also showed that the virus mainly infected dromedary calves and the sero-positivity rate increased with the age of the dromedaries [78]. Although MERS-CoV is not present in wild Bactrian camels, those that were intranasally inoculated with the virus did develop symptoms and the virus could also be isolated from their respiratory samples as well as being seroconverted [79]. Moreover, we have also detected MERS-CoV neutralizing antibodies in Bactrian camels in Dubai, The United Arab Emirates. These indicated that Bactrian camels could also be potential reservoirs of MERS-CoV [80]. 

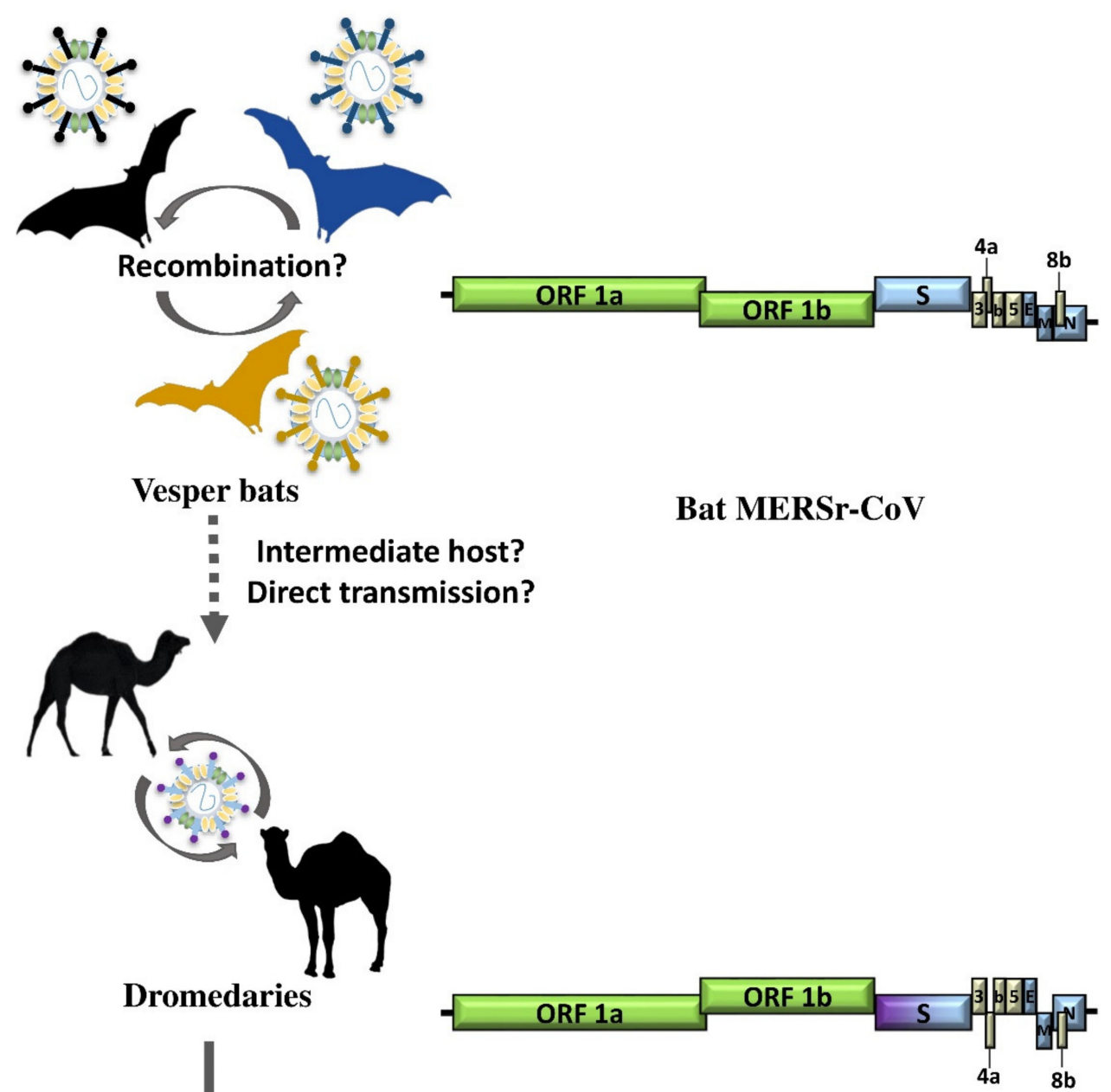

Bat MERSr-CoV

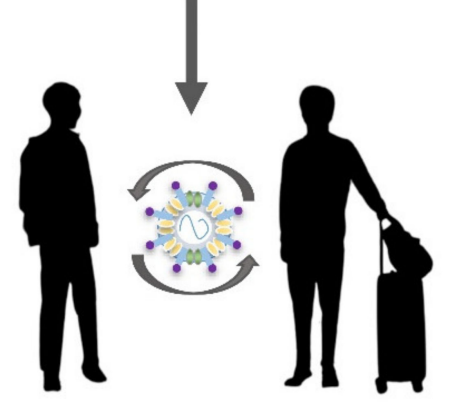

Human / Camel MERS-CoV

\section{Human populations}

Figure 3. Overview of interspecies transmission events of MERS epidemic since 2012. Arrows indicate the direction of viral interspecies jumping between different host species. Circular arrows indicate the circulation of virus within the population. Dot arrows indicate the viral interspecies jumping event remains to be elucidated. ORF1a and ORF1b are represented by green boxes, structural proteins by blue and purple boxes, and accessory proteins by yellow boxes.

The size of the MERS-CoV genome is around 30,110 bp. When it was discovered, it was found to be most closely related to Tylonycteris bat CoV HKU4 (Ty-BatCoV HKU4), Pipistrellus bat CoV HKU5 (Pi-BatCoV HKU5), that we discovered from the fecal samples of lesser bamboo bat (Tylonycteris pachypus) and Japanese pipistrelle (Pipistrellus abramus), respectively, in 2006 [64,81,82]. MERS-CoV, Ty-BatCoV HKU4, and Pi-BatCoV HKU5 all belong to the subgenus Merbecovirus in Betacoronavirus, and they share similar genome size and organization (Figure 3) [81,82]. In addition to the basic genome backbone $5^{\prime}$ ORF1ab-S-E-M-N-3', several ORFs that encode accessory proteins, including ORF3, ORF4a, ORF4b, ORF5 and ORF8b, are present (Figure 3 and Table 2) [70]. Despite these similarities, MERS-CoV, Ty-BatCoV HKU4 and Pi-BatCoV HKU5 are not as closely related to each other 
as bat, civet and human SARSr-CoVs $[81,82]$. Therefore, it has boosted interest in the search for additional merbecoviruses, with the aim of identifying ancestors that are more closely related to MERS-CoV than Ty-BatCoV HKU4 and Pi-BatCoV HKU5. In the past few years, several merbecoviruses were discovered in other bat species, as well as hedgehogs. These include Hypsugo pulveratus bat coronavirus HKU25, Neoromicia/PML-PHE1/RSA/2011, BatCoV PREDICT/PDF-2180, MERSr-CoV isolates NL140422, Hedgehog coronavirus 1, Erinaceus amurensis hedgehog coronavirus HKU31, BtVs-BetaCoV SC2013 and MERSr-CoV isolate Bat-CoV/P.khulii/Italy/206645-63/2011 (Figure 4) [27,83-89].

Table 2. Putative functions of MERS-CoV accessory proteins.

\begin{tabular}{|c|c|}
\hline Accessory Protein & Putative Function(s) \\
\hline ORF3 & Inhibits type I IFN responses [90] \\
\hline ORF4a & $\begin{array}{c}\text { Inhibits MDA5-mediated IFN activation [91]; } \\
\text { interferes in PKR-mediated antiviral stress responses [92] }\end{array}$ \\
\hline ORF4b & Inhibits type I IFN responses by interacting with TBK1 and IKK $\varepsilon$ [93] \\
\hline ORF5 & Reduces NF- $\mathrm{kB}$ activation and inflammatory cytokines [90] \\
\hline ORF8b & $\begin{array}{l}\text { Inhibits IFN- } \beta \text { promoter activity by RIG-I [94]; } \\
\text { suppresses IKK } \varepsilon \text { activated type I IFN responses [95] }\end{array}$ \\
\hline
\end{tabular}
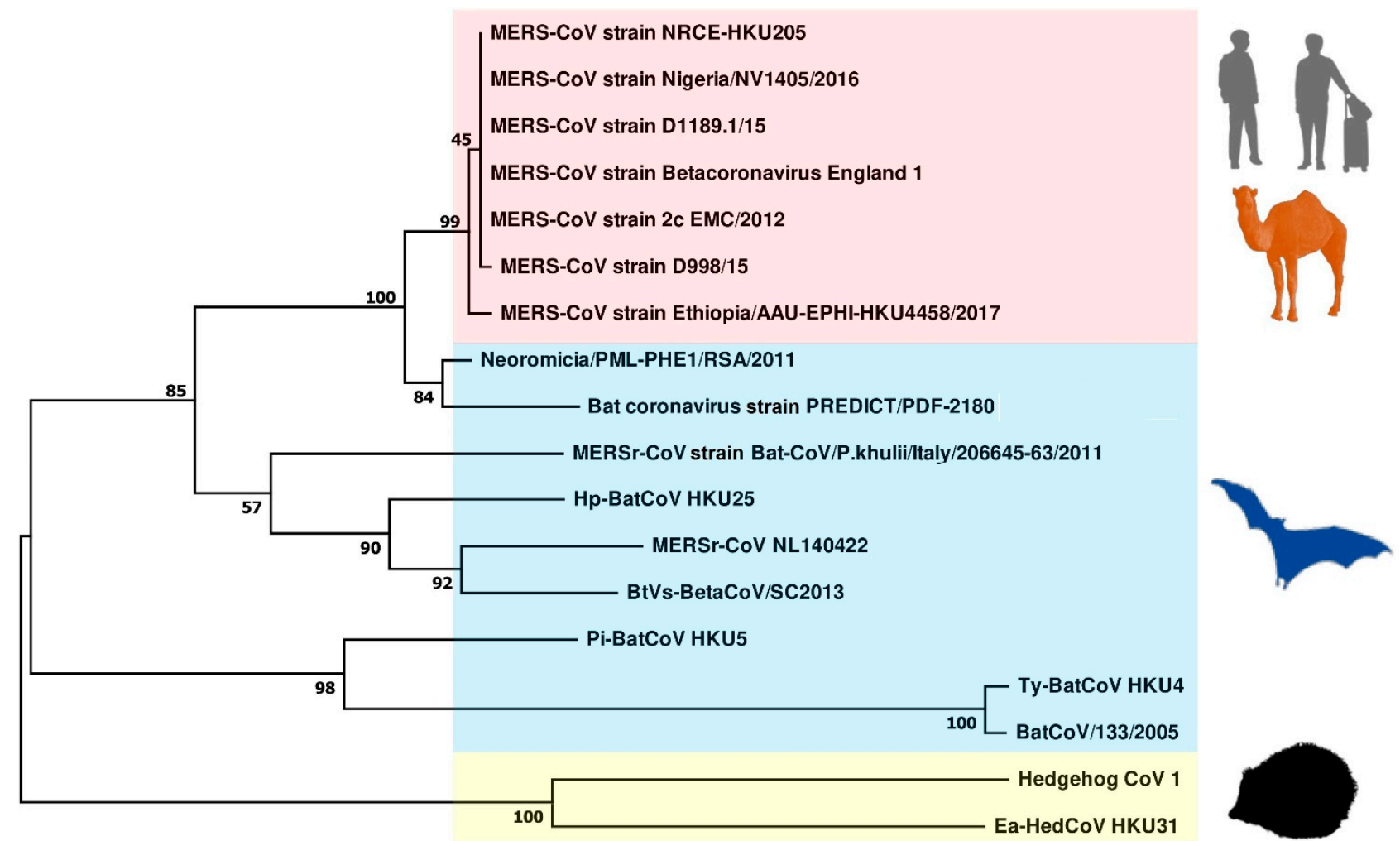

0.02

Figure 4. Maximum-likelihood phylogeny based on the nsp12 amino acid sequences of selected MERSr-CoVs and merbecoviruses. A Jones-Taylor-Thornton (JTT) model of amino acid substitution was used in the analysis with a discrete gamma $(\gamma)$ distribution. 1000 trees were set for bootstrap values calculation. All bootstrap values and the scale bar indicating the number of amino acid substitutions per site are shown. Viral strains highlighted in red color represents the MERSr-CoV cluster, blue color represents the bat merbecoviruses cluster, yellow color represents the hedgehog merbecoviruses cluster. 
The receptor of MERS-CoV is human dipeptidyl peptidase (hDPP4) [30,96]. Detailed phylogenetic analysis and comparison of the S proteins of MERS-CoV, Ty-BatCoV HKU4 and $P i$-BatCoV HKU5 revealed that the $S$ protein of MERS-CoV is more related to that of Ty-BatCoV HKU4 and Pi-BatCoV HKU5 [81,82]. It was also shown that the S protein of Ty-BatCoV HKU4, but not that of Pi-BatCoV HKU5, can bind hDPP4 [97,98]. Recently, we have isolated Ty-BatCoV HKU4 using Caco-2 and Huh-7 cells and found that it was able to infect transgenic mice expressing hDDP4, showing pathologies similar to, but less severe than, those infected with MERS-CoV [99]. These indicated that Ty-BatCoV HKU4 or its close relative is likely sharing the common ancestor of MERS-CoV.

\section{Rhinolophus Bat CoV HKU2: Another CoV from Horseshoe Bats}

In 2006, in the same study in which we described the discovery of Ty-BatCoV HKU4 and $P i$-BatCoV HKU5, we also first reported the discovery of Rhinolophus bat CoV HKU2 ( $R h$-BatCoV HKU2) from $8.3 \%$ of the fecal samples of Chinese horseshoe bats (R. sinicus) in Hong Kong, sharing the same host as bat SARSr-CoV (Figure 5) [100]. Unlike the SARSr$\mathrm{CoVs}$ and MERSr-CoVs that are betaCoVs, Rh-BatCoV HKU2 belongs to another genus, Alphacoronavirus, which is highly diversified [5,62,63,101-104]. After Rh-BatCoV HKU2 was discovered in Chinese horseshoe bats from Hong Kong, similar to the situation of SARSr-CoVs, it was also found in intermediate horseshoe bats, Chinese horseshoe bats, least horseshoe bats, king horseshoe bats, big-eared horseshoe bats, greater horseshoe bats, eastern bent-wing bats, great roundleaf bats, and Pratt's roundleaf bats from mainland China, and Shamel's horseshoe bats from Thailand, respectively [54,105-107]. However, the genomes of these strains, except one from an intermediate horseshoe bat (isolate 160,660) and one from a greater horseshoe bat (isolate BtRf-AlphaCoV/YN2012) in China, were not sequenced and analyzed [105,107].
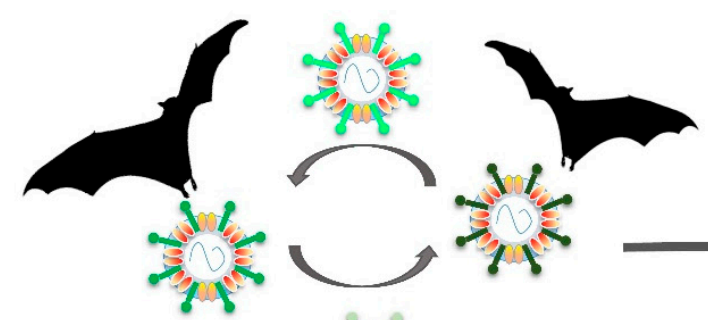

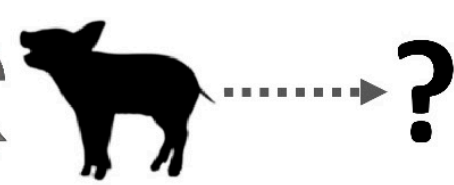

Piglets

\section{Rhinolophus bats}

$R h$-BatCoV HKU2
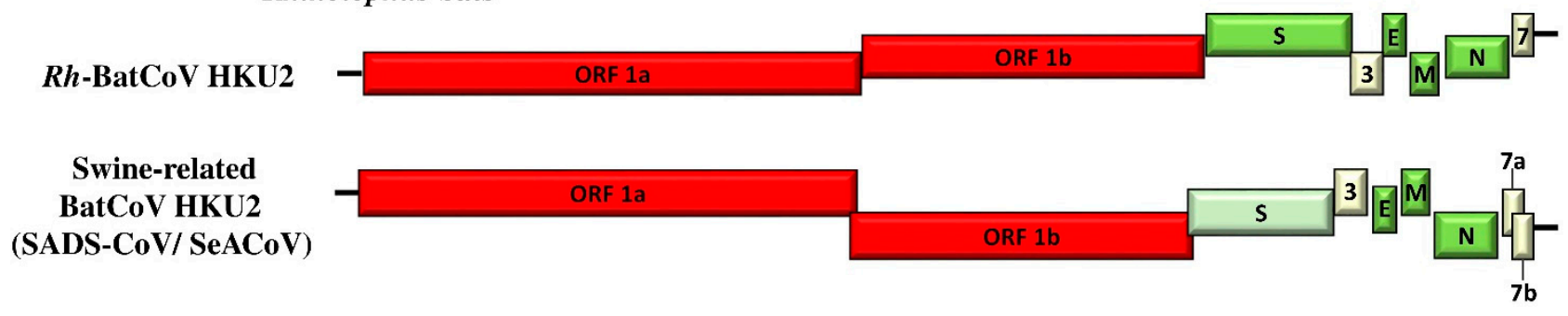

Figure 5. Overview of interspecies transmission events of swine-related BatCoV HKU2 (SADS) outbreak since 2017. Arrows indicate the direction of viral interspecies jumping between different host species. Circular arrows indicate the circulation of virus within the population. Dot arrows indicate the viral interspecies jumping event remains to be elucidated.

The size of the $R h$-BatCoV HKU2 genome is only around $27 \mathrm{~kb}$, the smallest among all the known CoVs [100]. In addition to the standard genome organization of 5'-ORF1ab-S-EM-N-3' , two accessory genes, ORF3 and ORF7 of unknown function to date, were observed (Figure 5) [100]. Notably, the $S$ protein of $R h$-BatCoV HKU2 has only 1128 amino acid 
residues, the shortest among all known CoVs. Phylogenetic analysis also showed that this $R h$-BatCoV HKU2 S protein forms a distinct branch, suggesting that it may have a unique evolutionary pathway [100]. It is of interest that in 2015 and 2017, two novel alphacoronaviruses, Lucheng Rattus norvegicus rat coronavirus (LRNV) and Wénchéng shrew virus (WESV) were reported in brown rat (Rattus norvegicus) and Asian house shrews (Suncus murinus) from mainland China $[108,109]$. Intriguingly, these two novel alphacoronaviruses also have short $S$ proteins, although distinct from that of $R h$-BatCoV HKU2 (only around $38-42 \%$ amino acid identity) as well as those of other known alphacoronaviruses [108,109].

In 2016, 10 years after the first discovery of $R h$-BatCoV HKU2 in Chinese horseshoe bats, a series of fatal swine disease outbreaks affecting newborn piglets was reported in several pig farms in Qingyuan of the Guangdong province in Southern China [107,110-112]. Porcine epidemic diarrhea virus (another alphaCoV) was initially considered as the causative agent for these outbreaks but subsequently it was no longer detected in the dead pigs despite the persistence of the outbreaks and increasing fatality [107]. The possibilities of other swine-related viruses, such as parvovirus, pseudorabies virus, rotavirus, foot and mouth disease virus, classical swine fever virus, sapelovirus, swine influenza virus, etc. were also excluded. Finally, by performing next generation sequencing on the piglet intestinal samples, $R h$-BatCoV HKU2 was unexpectedly identified, and its causative role was subsequently confirmed by viral isolation in tissue culture and other experiments to fulfil Koch's postulates (Figure 5) [107,110]. Two groups of Chinese scientists named this $R h$-BatCoV HKU2 found in the piglets as swine enteric alphacoronavirus (SeACoV) and swine acute diarrhea syndrome coronavirus (SADS-CoV) respectively, pending validation by the ICTV $[107,111,113]$. After the initial outbreaks, another strain was detected in seven pig farms in the Fujian Province in 2018, and re-emergence of the fatal swine disease due to this virus was also reported in February 2019, leading to around 2000 piglet deaths in a pig farm of the Guangdong Province, near the origin of the previous outbreak [114]. So far, this novel swine enteric disease has not been reported outside China. However, the sporadic outbreaks of the disease suggest that multiple interspecies jumping events might have occurred between the bat and swine populations, similar to the case of MERS-CoV with polyphyletic origin $[113,115]$.

Being the same species, there is an overall $87-95 \%$ nucleotide sequence identity between SeACoV/SADS-CoV and Rh-BatCoV HKU2 [107,110,111]. However, the S gene of SeACoV/SADS-CoV shows only around 73-86\% amino acid sequence identity to that of $R h$-BatCoV HKU2, indicating that significant changes in the $S$ protein are required for its binding to the corresponding receptor in pigs, leading to interspecies jumping. This theory was further supported by the discovery of four additional Rh-BatCoV HKU2 strains, named SADSr-CoV strains 141,388, 162,140, 8495 and 8462, collected from intermediate horseshoe bats and unspecified horseshoe bats in 2013-2016 from the Guangdong province of China (Figure 6) [107]. These four strains shared 96-98\% overall nucleotide sequence identity with SeACoV/SADS-CoV. Moreover, the S genes of SADSr-CoV strains 141,388 and 162,140 shared $>98 \%$ amino acid sequence identity with that of SeACoV/SADS$\mathrm{CoV}$ [107]. Importantly, an additional accessory gene, ORF7b, was found to be present only in SeACoV/SADS-CoV and some of the recently discovered $R h$-BatCoV HKU2 strains (SADSr-CoV strains 162,140 and 8462), suggesting that multiple steps might have occurred for the interspecies jumping event between bats and pigs to happen (Figure 5) [107]. 


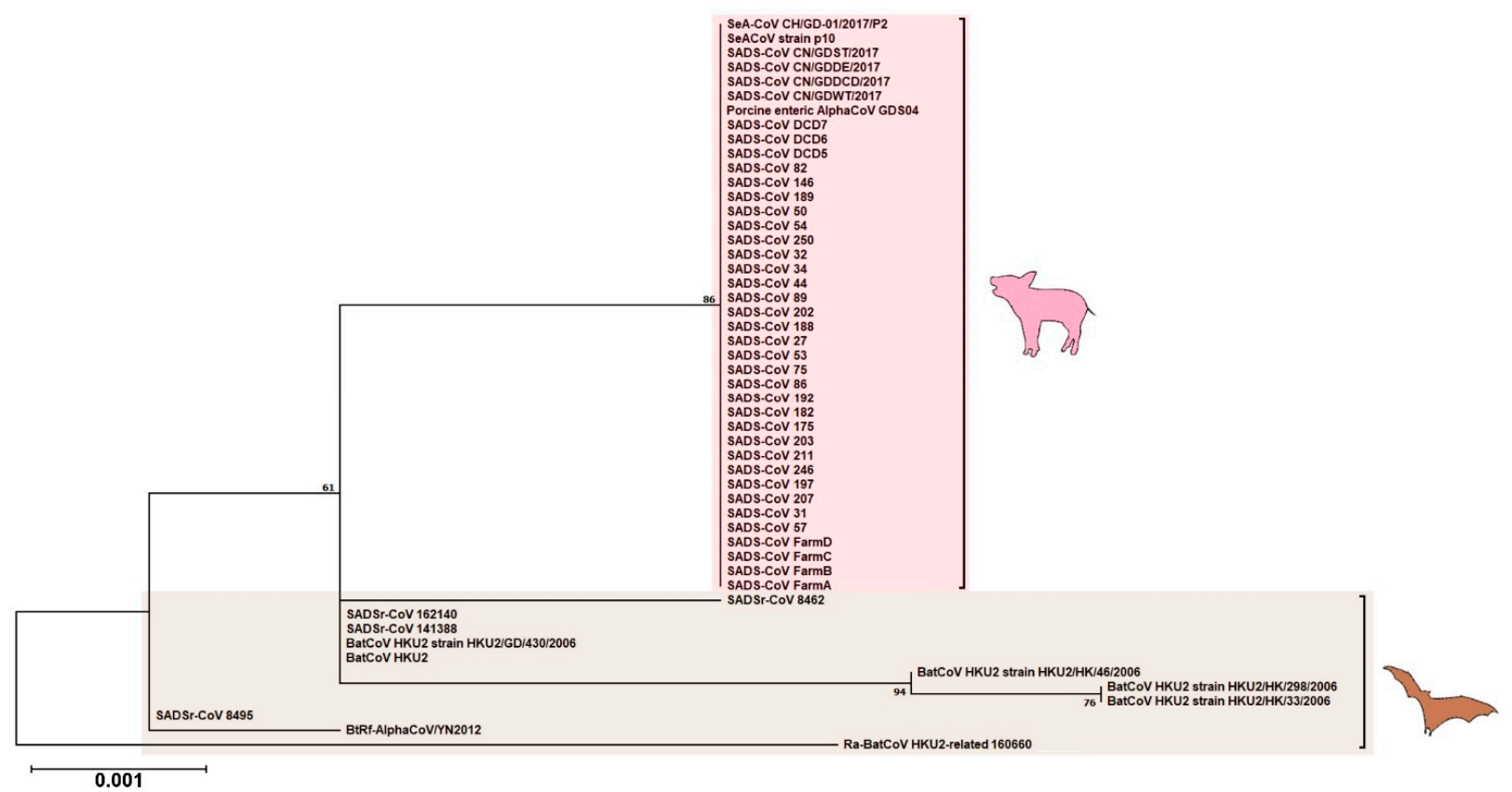

(a)

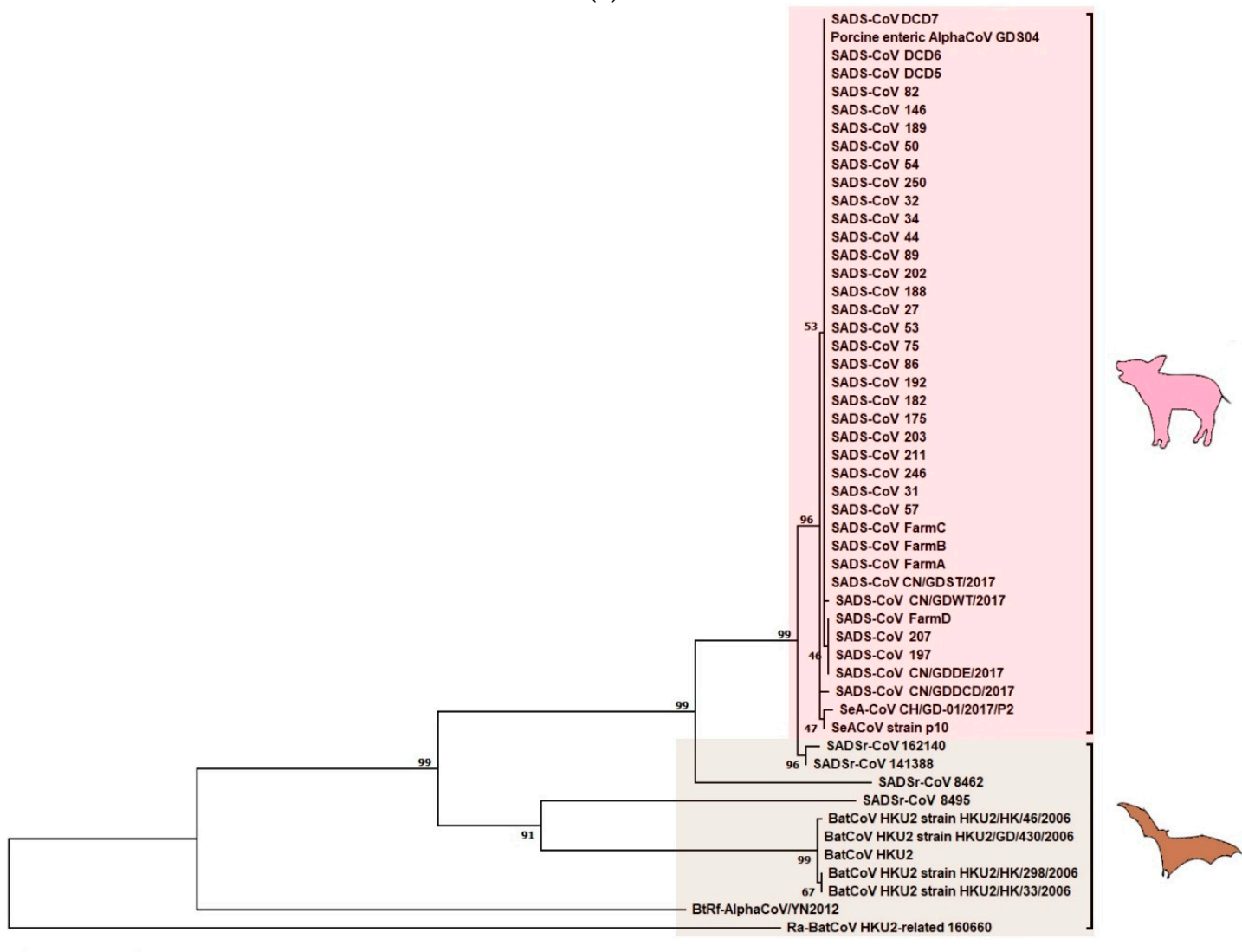

(b)

Figure 6. Maximum-likelihood phylogeny based on the amino acid sequences of selected BatCoV HKU2 and swine-related BatCoV HKU2 (a) nsp12 and (b) S1 domains. (a) a Jones-Taylor-Thornton (JTT) model of amino acid substitution and (b) a Whelan-Goldman matrix (WAG) model with a discrete gamma $(\gamma)$ distribution of amino acid substitution was used in the respective analyses. 1000 trees were set for bootstrap values calculation. All bootstrap values and the scale bars indicating the number of amino acid substitutions per site are shown. Viral strains highlighted in pink color represents Table 2 cluster; brown color represents the BatCoV HKU2 cluster. 


\section{SARS-CoV-2: The SARS-CoV Story Retold?}

In late 2019, an outbreak of pneumonia cases occurred in Wuhan, China. The infection rapidly spread to every single country in the world in 2020, leading to countless people losing their lives or having permanent lung damage [116]. By 1 October 2021, there have already been more than 5 million laboratory confirmed fatalities; and the infection, named COVID-19 by the World Health Organization, is still raging worldwide, despite the availability of reasonably effective mRNA vaccines developed by Moderna, Inc and Biopharmaceutical New Technologies (BioNTech SE), as well as recombinant adenoviral vector encoding SARS-CoV-2 spike protein vaccines developed by AstraZeneca plc and Johnson \& Johnson (J\&J) within one year of the beginning of the pandemic [117-119]. However, patient zero is still unknown and neither is the original source of the pandemic [120-122]. A CoV closely related to the SARSr-CoVs, belonging to the subgenus Sarbecovirus of Betacoronavirus, has been isolated from COVID-19 patients. The CoV was subsequently named as SARS-CoV-2, distinguishing it from the SARS-CoV that caused the SARS epidemic in 2003 [123]. In contrast to SARS-CoV, SARS-CoV-2 has been circulating in humans for almost two years already. Several factors have contributed to the enormous differences in the scale and consequence of the SARS and COVID-19 outbreaks. First, the emergence of SARS-CoV-2 from an unknown source posed difficulties in conducting blocking tactics. There is no concrete scientific evidence so far showing whether the interspecies transmission was directly from bats to humans or if any intermediate animal host was involved [124]. Second, many countries have missed the chance of implementing early infection control tactics, such as wearing masks, quarantine and travel restrictions, leading to uncontrollable viral transmission links established globally instead of restricting the early outbreak within a target population [125]. Third, SARS-CoV-2 has displayed highly human-adapted characteristics and a rapid transmission rate within the human population since its first emergence $[126,127]$. Epidemiologically, the 7.8 billion human population, which exceeds the critical community size, has provided a large and stable maintenance population for SARS-CoV-2 to circulate and adapt. The emergence of many variants of interest and concern through mutation has made it difficult to achieve complete eradication through reservoir control measures, such as global mass vaccination, as it has been shown that some of the novel variants may escape existing available vaccine protection [128-131]. Therefore, it is possible that humans may become a new permanent component contributing to the reservoir of SARS-CoV-2, which would be the fifth persisting human $\mathrm{CoV}(\mathrm{HCoV})$ after HCoV-OC43, HCoV-229E, HCoV-NL63 and HCoVHKU1 [132-137]. Although no animal reservoir was identified and no animal-to-human transmission documented, the virus has been shown to infect a number of mammals, including dogs, domestic cats, lions, tigers, snow leopards, cougars, pumas, ferrets, minks and gorillas globally (Figures 2 and 7) [138-141]. However, it appears that most of these animal infections, except for minks which can transmit SARS-CoV-2 back to human, were dead-end infections, as they have not yet resulted in any further spread of the disease, suggesting that these animals belong to the non-maintenance population (Figure 7). 


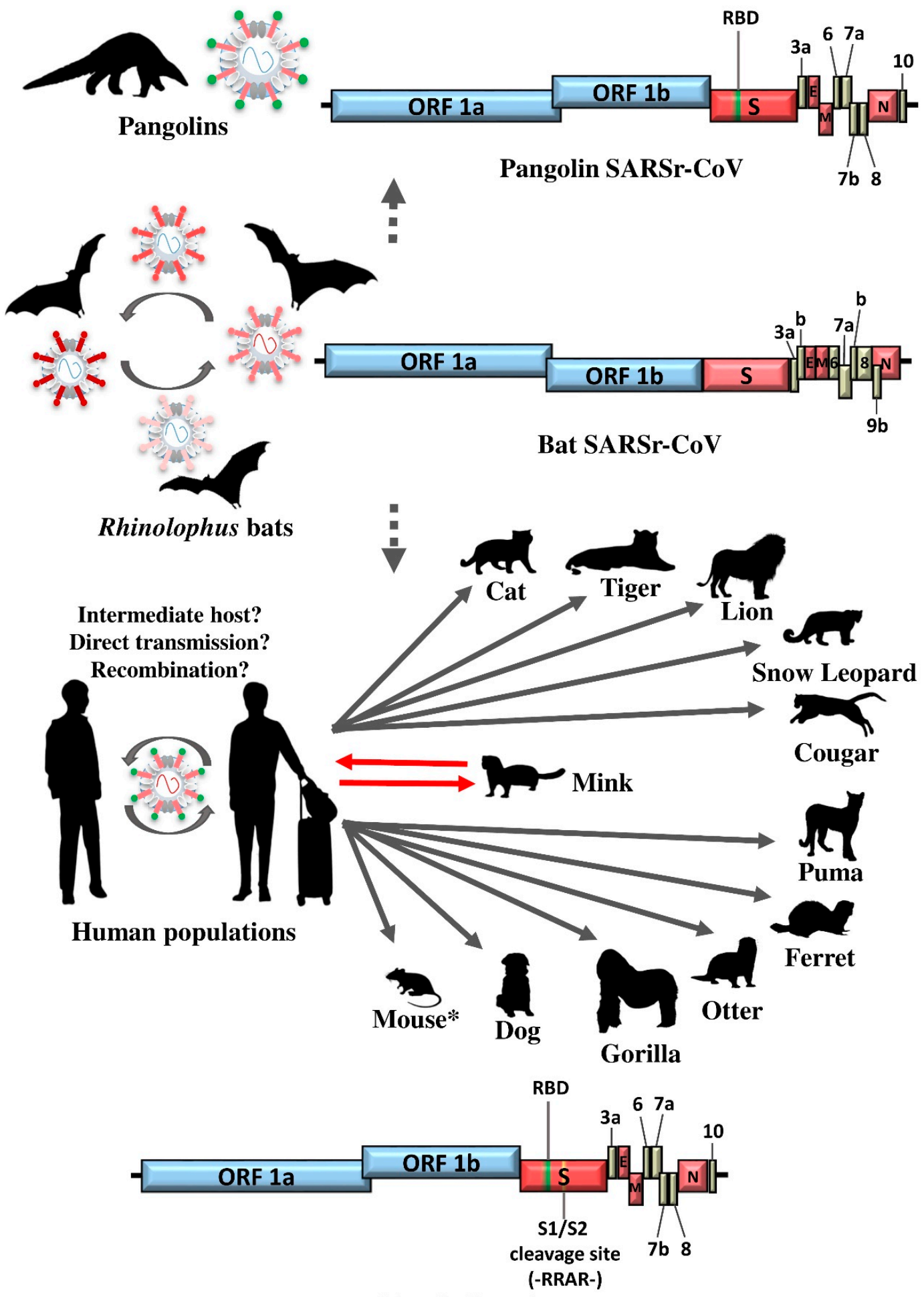

SARS-CoV-2

Figure 7. Overview of interspecies transmission events of COVID-19 pandemic since 2019. Arrows indicate the direction of viral interspecies jumping and viral molecular evolution between different host species. Circular arrows indicate the circulation of virus within the population. Dot arrows indicate the viral interspecies jumping event remains to be elucidated. Red arrows indicate the bi-directionality of interspecies jumping events. Asterisk labeled animal represents the laboratory interspecies jumping event through host adaption. ORF1a and ORF1b are represented by blue boxes, structural proteins by red boxes, and accessory proteins by yellow boxes. The RBD and the -RRAR- cleavage site are highlighted in green and yellow respectively. 
The genome size of SARS-CoV-2 is around $29,903 \mathrm{~kb}$, similar to that of other SARSrCoVs $[116,120]$. It also shares similar genomic organization as the SARSr-CoVs found in various species of horseshoe bats, consisting of the basic genome backbone $5^{\prime}-\mathrm{ORF} 1 \mathrm{ab}-$ S-E-M-N-3' and a similar set of ORFs that encode accessory proteins, including ORF3a, ORF6, ORF7a, ORF7b, ORF8 and ORF10 (Figure 7) [120]. Despite these similarities, the difference in the sequences of the individual genes, particularly the $S$ protein, have led to the differential phenotypes and virulence between SARS-CoV-2 and the other SARSr-CoVs found in bats, civets and human in the previous epidemic, and hence different clinical manifestations of SARS and COVID-19 [142-147]. In fact, the RBD region of the S protein in SARS-CoV-2 only shares around $74-77 \%$ amino acid identity with those of human, civet and bat SARSr-CoVs that were previously reported before the COVID-19 outbreak, although these SARSr-CoVs can all utilize human ACE2 despite their different binding affinities [143,148-152]. Shortly after the beginning of the pandemic, two independent groups have found in their surveillance studies that SARSr-CoVs were detected in pangolins in the Guangdong province of southern China and that the RBD region of the $S$ protein in SARS-CoV-2 shares the closest relationship ( $97 \%$ amino acid identity) with those observed in these pangolin SARSr-CoVs $[153,154]$. In addition, a recent pre-print research article has described the discovery of a bat SARSr-CoV strain BANAL-20-52 from the Indochinese peninsula, which also carries an RBD region with $\sim 97 \%$ amino acid identity to that of SARS-CoV-2 [155].

Until now, undeniably one of the most intriguing aspects in the genome of SARS-CoV2 is located at the S1/S2 junction. A unique, short amino acid (PRRA) insertion is found within the $S$ gene of SARS-CoV-2, leading to a potential furin cleavage site (RRAR) between the S1 and S2 subunits (Figure 7) [31,152]. Such an insertion allows the SASRS-CoV-2 $S$ protein to undergo proteolytic cleavage, resulting in cell-cell fusion enhancement and contributes to pathogenesis [31,156-158]. It is of note that the additional cleavage site in the $\mathrm{S}$ gene has not been observed in any bat SARSr-CoV strains discovered so far since 2003, including those recently discovered in southeast Asia [155,159-163], nor in any pangolin SARS-CoV-2 strains $[153,154,161]$. This has raised concerns in both the scientific community and the general public globally, pending further research into its possible origin.

\section{Concluding Remarks}

Due to the absence of existing immunity, infections caused by a novel virus as a result of recombination, reassortment and/or mutations and subsequent interspecies jumping, have often led to epidemics that can be highly lethal. In CoVs, this has been well exemplified in the last two decades in three independent pandemics, two originated in China and one from the Middle East. The first two, the SARS and MERS epidemics in 2003 and 2012, respectively, have been confirmed to be transmitted from animal reservoirs to humans [164-166]. Thorough and scientific investigations on the origin of COVID-19 and the potential threat of $R h$-BatCoV HKU2-related swine disease are yet to be completed $[167,168]$. Recent research advancement in viral pathogenesis studies by artificial manipulation of viral genomes like recombineering experiments may lead to the generation of novel pathogens with unpredictable virulence [23]. Therefore, performing animal surveillance studies, controlling animal food markets, implementing good hygienic measures during animal contacts, etc. are essential for mitigating possible future outbreaks while having a global concerted effort to regulate and monitor viral genetic engineering experiments is of crucial importance to secure a safe research environment [21].

Author Contributions: Conceptualization, A.C.P.W., S.K.P.L. and P.C.Y.W.; methodology, A.C.P.W.; software, A.C.P.W.; validation, A.C.P.W., S.K.P.L. and P.C.Y.W.; formal analysis, A.C.P.W., S.K.P.L. and P.C.Y.W.; investigation, A.C.P.W., S.K.P.L. and P.C.Y.W.; data curation, A.C.P.W.; writing-original draft preparation, A.C.P.W., S.K.P.L. and P.C.Y.W.; writing-review and editing, A.C.P.W., S.K.P.L. and P.C.Y.W.; visualization, A.C.P.W. and P.C.Y.W.; supervision, S.K.P.L. and P.C.Y.W.; funding acquisition, S.K.P.L. and P.C.Y.W. All authors have read and agreed to the published version of the manuscript. 
Funding: This research was partly funded by: the Theme-based Research Scheme (Project No. T11707/15-R), University Grant Committee; Consultancy Service for Enhancing Laboratory Surveillance of Emerging Infectious Diseases and Research Capability on Antimicrobial Resistance for the Department of Health, HKSAR Government; and the Health and Medical Research Fund of the Food and Health Bureau of HKSAR (COVID190122) and (CID-HKU1-6).

Data Availability Statement: Data available in publicly accessible repositories. The data presented in this study are openly available in National Center for Biotechnology Information and GISAID Initiative.

Conflicts of Interest: The authors declare no conflict of interest.

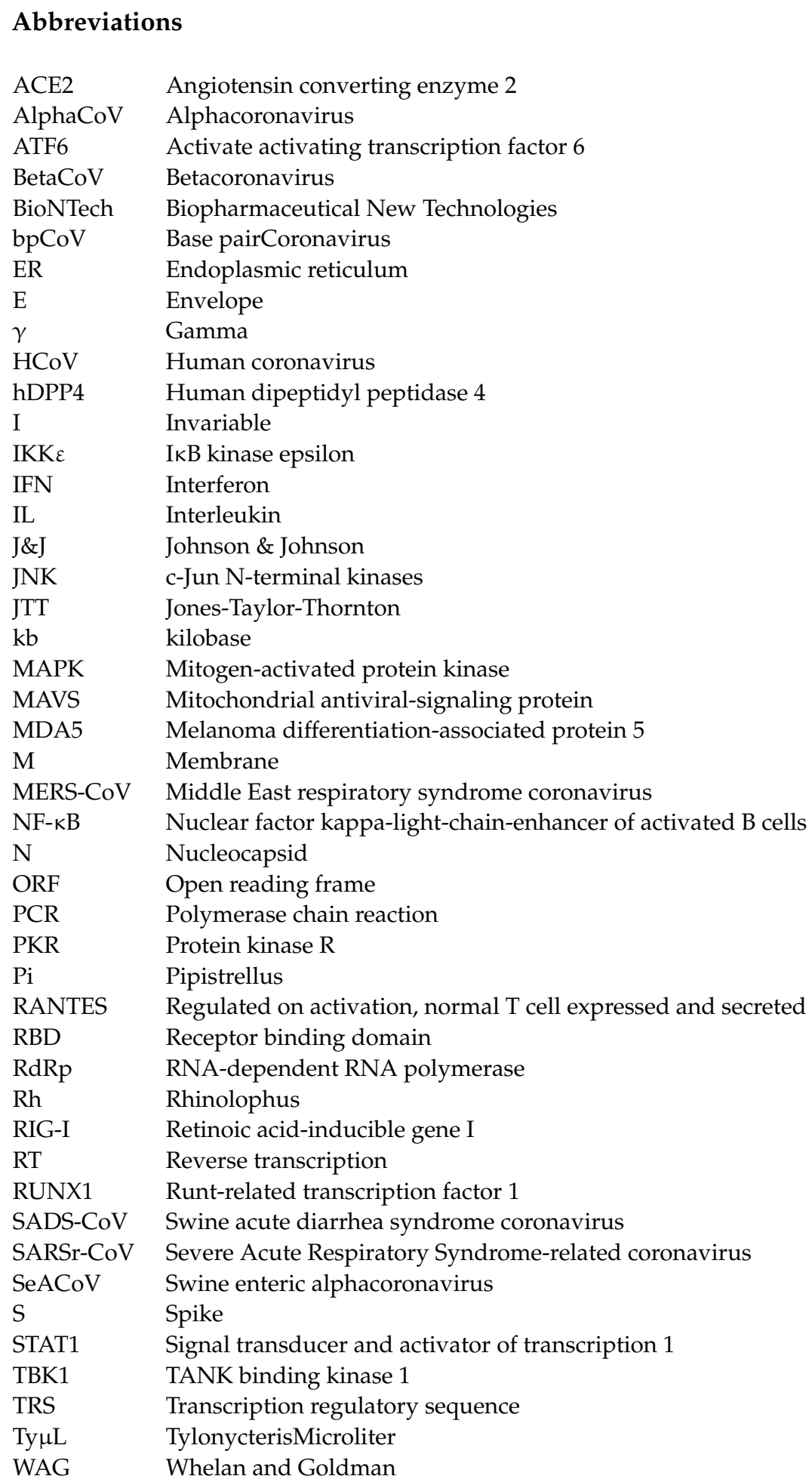




\section{References}

1. ICTV Taxonomy History: Cornidovirineae. Available online: https://talk.ictvonline.org/taxonomy/p/taxonomy-history? taxnode_id=20186105 (accessed on 2 January 2019).

2. Baltimore, D. Expression of animal virus genomes. Bacteriol. Rev. 1971, 35, 235-241. [CrossRef] [PubMed]

3. Lai, M.M.; Stohlman, S.A. Comparative analysis of RNA genomes of mouse hepatitis viruses. J. Virol. 1981, 38, 661-670. [CrossRef]

4. De Vries, A.A.F.; Horzinek, M.C.; Rottier, P.J.M.; de Groot, R.J. The Genome Organization of the Nidovirales: Similarities and Differences between Arteri-, Toro-, and Coronaviruses. Semin. Virol. 1997, 8, 33-47. [CrossRef]

5. $\quad$ Lau, S.K.P.; Wong, A.C.P.; Zhang, L.; Luk, H.K.H.; Kwok, J.S.L.; Ahmed, S.S.; Cai, J.P.; Zhao, P.S.H.; Teng, J.L.L.; Tsui, S.K.W.; et al. Novel Bat Alphacoronaviruses in Southern China Support Chinese Horseshoe Bats as an Important Reservoir for Potential Novel Coronaviruses. Viruses 2019, 11, 423. [CrossRef]

6. Chinese, S.M.E.C. Molecular evolution of the SARS coronavirus during the course of the SARS epidemic in China. Science 2004, 303, 1666-1669. [CrossRef]

7. Chiu, R.W.; Chim, S.S.; Tong, Y.K.; Fung, K.S.; Chan, P.K.; Zhao, G.P.; Lo, Y.M. Tracing SARS-coronavirus variant with large genomic deletion. Emerg. Infect. Dis. 2005, 11, 168-170. [CrossRef]

8. Guan, Y.; Zheng, B.J.; He, Y.Q.; Liu, X.L.; Zhuang, Z.X.; Cheung, C.L.; Luo, S.W.; Li, P.H.; Zhang, L.J.; Guan, Y.J.; et al. Isolation and characterization of viruses related to the SARS coronavirus from animals in southern China. Science 2003, 302, 276-278. [CrossRef]

9. Liu, D.X.; Fung, T.S.; Chong, K.K.; Shukla, A.; Hilgenfeld, R. Accessory proteins of SARS-CoV and other coronaviruses. Antiviral Res. 2014, 109, 97-109. [CrossRef]

10. Casais, R.; Davies, M.; Cavanagh, D.; Britton, P. Gene 5 of the avian coronavirus infectious bronchitis virus is not essential for replication. J. Virol. 2005, 79, 8065-8078. [CrossRef] [PubMed]

11. De Haan, C.A.; Masters, P.S.; Shen, X.; Weiss, S.; Rottier, P.J. The group-specific murine coronavirus genes are not essential, but their deletion, by reverse genetics, is attenuating in the natural host. Virology 2002, 296, 177-189. [CrossRef]

12. Haijema, B.J.; Volders, H.; Rottier, P.J. Live, attenuated coronavirus vaccines through the directed deletion of group-specific genes provide protection against feline infectious peritonitis. J. Virol. 2004, 78, 3863-3871. [CrossRef]

13. Hodgson, T.; Britton, P.; Cavanagh, D. Neither the RNA nor the proteins of open reading frames $3 a$ and $3 b$ of the coronavirus infectious bronchitis virus are essential for replication. J. Virol. 2006, 80, 296-305. [CrossRef] [PubMed]

14. Ontiveros, E.; Kuo, L.; Masters, P.; Perlman, S. Analysis of nonessential gene function in recombinant MHV-JHM. Gene 4 knockout recombinant virus. Adv. Exp. Med. Biol. 2001, 494, 83-89. [CrossRef]

15. Shen, S.; Wen, Z.L.; Liu, D.X. Emergence of a coronavirus infectious bronchitis virus mutant with a truncated $3 \mathrm{~b}$ gene: Functional characterization of the $3 \mathrm{~b}$ protein in pathogenesis and replication. Virology 2003, 311, 16-27. [CrossRef]

16. Yount, B.; Roberts, R.S.; Sims, A.C.; Deming, D.; Frieman, M.B.; Sparks, J.; Denison, M.R.; Davis, N.; Baric, R.S. Severe acute respiratory syndrome coronavirus group-specific open reading frames encode nonessential functions for replication in cell cultures and mice. J. Virol. 2005, 79, 14909-14922. [CrossRef]

17. Wong, A.C.P.; Li, X.; Lau, S.K.P.; Woo, P.C.Y. Global Epidemiology of Bat Coronaviruses. Viruses 2019, 11, 174. [CrossRef]

18. Fehr, A.R.; Perlman, S. Coronaviruses: An overview of their replication and pathogenesis. Methods Mol. Biol. 2015, 1282, 1-23. [CrossRef]

19. Zhang, C.Y.; Wei, J.F.; He, S.H. Adaptive evolution of the spike gene of SARS coronavirus: Changes in positively selected sites in different epidemic groups. BMC Microbiol. 2006, 6, 88. [CrossRef]

20. Walls, A.C.; Tortorici, M.A.; Bosch, B.J.; Frenz, B.; Rottier, P.J.M.; DiMaio, F.; Rey, F.A.; Veesler, D. Cryo-electron microscopy structure of a coronavirus spike glycoprotein trimer. Nature 2016, 531, 114-117. [CrossRef]

21. Lau, S.K.P.; Woo, P.C.Y. Engineering Coronaviruses to Evaluate Emergence and Pathogenic Potential. Trends Microbiol. 2016, 24, 427-429. [CrossRef]

22. Roberts, A.; Deming, D.; Paddock, C.D.; Cheng, A.; Yount, B.; Vogel, L.; Herman, B.D.; Sheahan, T.; Heise, M.; Genrich, G.L.; et al. A mouse-adapted SARS-coronavirus causes disease and mortality in BALB/c mice. PLoS Pathog. 2007, 3, e5. [CrossRef] [PubMed]

23. Kilianski, A.; Nuzzo, J.B.; Modjarrad, K. Gain-of-Function Research and the Relevance to Clinical Practice. J. Infect. Dis. 2016, 213, 1364-1369. [CrossRef] [PubMed]

24. Menachery, V.D.; Yount, B.L., Jr.; Sims, A.C.; Debbink, K.; Agnihothram, S.S.; Gralinski, L.E.; Graham, R.L.; Scobey, T.; Plante, J.A.; Royal, S.R.; et al. SARS-like WIV1-CoV poised for human emergence. Proc. Natl. Acad. Sci. USA 2016, 113, 3048-3053. [CrossRef]

25. Menachery, V.D.; Yount, B.L., Jr.; Debbink, K.; Agnihothram, S.; Gralinski, L.E.; Plante, J.A.; Graham, R.L.; Scobey, T.; Ge, X.Y.; Donaldson, E.F.; et al. A SARS-like cluster of circulating bat coronaviruses shows potential for human emergence. Nat. Med. 2015, 21, 1508-1513. [CrossRef]

26. Ge, X.Y.; Li, J.L.; Yang, X.L.; Chmura, A.A.; Zhu, G.; Epstein, J.H.; Mazet, J.K.; Hu, B.; Zhang, W.; Peng, C.; et al. Isolation and characterization of a bat SARS-like coronavirus that uses the ACE2 receptor. Nature 2013, 503, 535-538. [CrossRef]

27. Luo, C.M.; Wang, N.; Yang, X.L.; Liu, H.Z.; Zhang, W.; Li, B.; Hu, B.; Peng, C.; Geng, Q.B.; Zhu, G.J.; et al. Discovery of Novel Bat Coronaviruses in South China That Use the Same Receptor as Middle East Respiratory Syndrome Coronavirus. J. Virol. 2018, 92, e00116-18. [CrossRef] [PubMed] 
28. He, Y.; Zhou, Y.; Liu, S.; Kou, Z.; Li, W.; Farzan, M.; Jiang, S. Receptor-binding domain of SARS-CoV spike protein induces highly potent neutralizing antibodies: Implication for developing subunit vaccine. Biochem. Biophys. Res. Commun. 2004, 324, 773-781. [CrossRef] [PubMed]

29. Li, F.; Li, W.; Farzan, M.; Harrison, S.C. Structure of SARS coronavirus spike receptor-binding domain complexed with receptor. Science 2005, 309, 1864-1868. [CrossRef]

30. Lu, G.; Hu, Y.; Wang, Q.; Qi, J.; Gao, F.; Li, Y.; Zhang, Y.; Zhang, W.; Yuan, Y.; Bao, J.; et al. Molecular basis of binding between novel human coronavirus MERS-CoV and its receptor CD26. Nature 2013, 500, 227-231. [CrossRef] [PubMed]

31. Xia, S.; Lan, Q.; Su, S.; Wang, X.; Xu, W.; Liu, Z.; Zhu, Y.; Wang, Q.; Lu, L.; Jiang, S. The role of furin cleavage site in SARS-CoV-2 spike protein-mediated membrane fusion in the presence or absence of trypsin. Signal. Transduct. Target Ther. $2020,5,92$. [CrossRef]

32. Chu, D.K.W.; Hui, K.P.Y.; Perera, R.; Miguel, E.; Niemeyer, D.; Zhao, J.; Channappanavar, R.; Dudas, G.; Oladipo, J.O.; Traore, A.; et al. MERS coronaviruses from camels in Africa exhibit region-dependent genetic diversity. Proc. Natl. Acad. Sci. USA 2018, 115, 3144-3149. [CrossRef] [PubMed]

33. Wu, Z.; Yang, L.; Ren, X.; Zhang, J.; Yang, F.; Zhang, S.; Jin, Q. ORF8-Related Genetic Evidence for Chinese Horseshoe Bats as the Source of Human Severe Acute Respiratory Syndrome Coronavirus. J. Infect. Dis. 2016, 213, 579-583. [CrossRef] [PubMed]

34. Lau, S.K.; Feng, Y.; Chen, H.; Luk, H.K.; Yang, W.H.; Li, K.S.; Zhang, Y.Z.; Huang, Y.; Song, Z.Z.; Chow, W.N.; et al. Severe Acute Respiratory Syndrome (SARS) Coronavirus ORF8 Protein Is Acquired from SARS-Related Coronavirus from Greater Horseshoe Bats through Recombination. J. Virol. 2015, 89, 10532-10547. [CrossRef]

35. Lau, S.K.; Li, K.S.; Tsang, A.K.; Shek, C.T.; Wang, M.; Choi, G.K.; Guo, R.; Wong, B.H.; Poon, R.W.; Lam, C.S.; et al. Recent transmission of a novel alphacoronavirus, bat coronavirus HKU10, from Leschenault's rousettes to pomona leaf-nosed bats: First evidence of interspecies transmission of coronavirus between bats of different suborders. J. Virol. 2012, 86, 11906-11918. [CrossRef]

36. Mackenzie, J.S.; Merianos, A. The legacies of SARS-International preparedness and readiness to respond to future threats in the Western Pacific Region. West. Pac. Surveill. Response J. 2013, 4, 4-8. [CrossRef]

37. Xu, R.H.; He, J.F.; Evans, M.R.; Peng, G.W.; Field, H.E.; Yu, D.W.; Lee, C.K.; Luo, H.M.; Lin, W.S.; Lin, P.; et al. Epidemiologic clues to SARS origin in China. Emerg. Infect. Dis. 2004, 10, 1030-1037. [CrossRef]

38. Hung, L.S. The SARS epidemic in Hong Kong: What lessons have we learned? J. R. Soc. Med. 2003, 96, 374-378. [CrossRef] [PubMed]

39. Lee, S.H. The SARS epidemic in Hong Kong. J. Epidemiol. Commun. Health 2003, 57, 652-654. [CrossRef]

40. Tsang, K.W.; Ho, P.L.; Ooi, G.C.; Yee, W.K.; Wang, T.; Chan-Yeung, M.; Lam, W.K.; Seto, W.H.; Yam, L.Y.; Cheung, T.M.; et al. A cluster of cases of severe acute respiratory syndrome in Hong Kong. N. Engl. J. Med. 2003, 348, 1977-1985. [CrossRef] [PubMed]

41. Zhong, N.S.; Zheng, B.J.; Li, Y.M.; Poon, L.L.M.; Xie, Z.H.; Chan, K.H.; Li, P.H.; Tan, S.Y.; Chang, Q.; Xie, J.P.; et al. Epidemiology and cause of severe acute respiratory syndrome (SARS) in Guangdong, People's Republic of China, in February, 2003. Lancet 2003, 362, 1353-1358. [CrossRef]

42. Kan, B.; Wang, M.; Jing, H.; Xu, H.; Jiang, X.; Yan, M.; Liang, W.; Zheng, H.; Wan, K.; Liu, Q.; et al. Molecular evolution analysis and geographic investigation of severe acute respiratory syndrome coronavirus-like virus in palm civets at an animal market and on farms. J. Virol. 2005, 79, 11892-11900. [CrossRef]

43. Tu, C.; Crameri, G.; Kong, X.; Chen, J.; Sun, Y.; Yu, M.; Xiang, H.; Xia, X.; Liu, S.; Ren, T.; et al. Antibodies to SARS coronavirus in civets. Emerg. Infect. Dis. 2004, 10, 2244-2248. [CrossRef]

44. Song, H.D.; Tu, C.C.; Zhang, G.W.; Wang, S.Y.; Zheng, K.; Lei, L.C.; Chen, Q.X.; Gao, Y.W.; Zhou, H.Q.; Xiang, H.; et al. Cross-host evolution of severe acute respiratory syndrome coronavirus in palm civet and human. Proc. Natl. Acad. Sci. USA 2005, 102, 2430-2435. [CrossRef]

45. Lau, S.K.; Woo, P.C.; Li, K.S.; Huang, Y.; Tsoi, H.W.; Wong, B.H.; Wong, S.S.; Leung, S.Y.; Chan, K.H.; Yuen, K.Y. Severe acute respiratory syndrome coronavirus-like virus in Chinese horseshoe bats. Proc. Natl. Acad. Sci. USA 2005, 102, 14040-14045. [CrossRef]

46. Yang, L.; Wu, Z.; Ren, X.; Yang, F.; He, G.; Zhang, J.; Dong, J.; Sun, L.; Zhu, Y.; Du, J.; et al. Novel SARS-like betacoronaviruses in bats, China, 2011. Emerg. Infect. Dis. 2013, 19, 989-991. [CrossRef]

47. Drexler, J.F.; Gloza-Rausch, F.; Glende, J.; Corman, V.M.; Muth, D.; Goettsche, M.; Seebens, A.; Niedrig, M.; Pfefferle, S.; Yordanov, S.; et al. Genomic Characterization of Severe Acute Respiratory Syndrome-Related Coronavirus in European Bats and Classification of Coronaviruses Based on Partial RNA-Dependent RNA Polymerase Gene Sequences. J. Virol. 2010, 84, 11336-11349. [CrossRef]

48. Rihtaric, D.; Hostnik, P.; Steyer, A.; Grom, J.; Toplak, I. Identification of SARS-like coronaviruses in horseshoe bats (Rhinolophus hipposideros) in Slovenia. Arch. Virol. 2010, 155, 507-514. [CrossRef] [PubMed]

49. Hu, B.; Zeng, L.P.; Yang, X.L.; Ge, X.Y.; Zhang, W.; Li, B.; Xie, J.Z.; Shen, X.R.; Zhang, Y.Z.; Wang, N.; et al. Discovery of a rich gene pool of bat SARS-related coronaviruses provides new insights into the origin of SARS coronavirus. PLoS Pathog. 2017, 13, e1006698. [CrossRef] [PubMed]

50. Liang, G.; Chen, Q.; Xu, J.; Liu, Y.; Lim, W.; Peiris, J.S.; Anderson, L.J.; Ruan, L.; Li, H.; Kan, B.; et al. Laboratory diagnosis of four recent sporadic cases of community-acquired SARS, Guangdong Province, China. Emerg. Infect. Dis. 2004, 10, $1774-1781$. [CrossRef] 
51. Poutanen, S.M.; Low, D.E.; Henry, B.; Finkelstein, S.; Rose, D.; Green, K.; Tellier, R.; Draker, R.; Adachi, D.; Ayers, M.; et al. Identification of severe acute respiratory syndrome in Canada. N. Engl. J. Med. 2003, 348, 1995-2005. [CrossRef] [PubMed]

52. Kuba, K.; Imai, Y.; Rao, S.; Gao, H.; Guo, F.; Guan, B.; Huan, Y.; Yang, P.; Zhang, Y.; Deng, W.; et al. A crucial role of angiotensin converting enzyme 2 (ACE2) in SARS coronavirus-induced lung injury. Nat. Med. 2005, 11, 875-879. [CrossRef] [PubMed]

53. Li, W.; Zhang, C.; Sui, J.; Kuhn, J.H.; Moore, M.J.; Luo, S.; Wong, S.K.; Huang, I.C.; Xu, K.; Vasilieva, N.; et al. Receptor and viral determinants of SARS-coronavirus adaptation to human ACE2. EMBO J. 2005, 24, 1634-1643. [CrossRef]

54. Lau, S.K.P.; Li, K.S.M.; Huang, Y.; Shek, C.T.; Tse, H.; Wang, M.; Choi, G.K.Y.; Xu, H.; Lam, C.S.F.; Guo, R.; et al. Ecoepidemiology and Complete Genome Comparison of Different Strains of Severe Acute Respiratory Syndrome-Related Rhinolophus Bat Coronavirus in China Reveal Bats as a Reservoir for Acute, Self-Limiting Infection That Allows Recombination Events. J. Virol. 2010, 84, 2808-2819. [CrossRef]

55. Kanzawa, N.; Nishigaki, K.; Hayashi, T.; Ishii, Y.; Furukawa, S.; Niiro, A.; Yasui, F.; Kohara, M.; Morita, K.; Matsushima, K.; et al. Augmentation of chemokine production by severe acute respiratory syndrome coronavirus $3 \mathrm{a} / \mathrm{X} 1$ and $7 \mathrm{a} / \mathrm{X} 4$ proteins through NF-kappaB activation. FEBS Lett. 2006, 580, 6807-6812. [CrossRef] [PubMed]

56. Varshney, B.; Agnihothram, S.; Tan, Y.J.; Baric, R.; Lal, S.K. SARS coronavirus 3b accessory protein modulates transcriptional activity of RUNX1b. PLoS ONE 2012, 7, e29542. [CrossRef]

57. Zhou, H.; Ferraro, D.; Zhao, J.; Hussain, S.; Shao, J.; Trujillo, J.; Netland, J.; Gallagher, T.; Perlman, S. The N-terminal region of severe acute respiratory syndrome coronavirus protein 6 induces membrane rearrangement and enhances virus replication. $J$. Virol. 2010, 84, 3542-3551. [CrossRef] [PubMed]

58. Kopecky-Bromberg, S.A.; Martinez-Sobrido, L.; Frieman, M.; Baric, R.A.; Palese, P. Severe acute respiratory syndrome coronavirus open reading frame (ORF) 3b, ORF 6, and nucleocapsid proteins function as interferon antagonists. J. Virol. 2007, 81, 548-557. [CrossRef] [PubMed]

59. Kopecky-Bromberg, S.A.; Martinez-Sobrido, L.; Palese, P. 7a protein of severe acute respiratory syndrome coronavirus inhibits cellular protein synthesis and activates p38 mitogen-activated protein kinase. J. Virol. 2006, 80, 785-793. [CrossRef]

60. Sung, S.C.; Chao, C.Y.; Jeng, K.S.; Yang, J.Y.; Lai, M.M. The 8ab protein of SARS-CoV is a luminal ER membrane-associated protein and induces the activation of ATF6. Virology 2009, 387, 402-413. [CrossRef] [PubMed]

61. Shi, C.S.; Qi, H.Y.; Boularan, C.; Huang, N.N.; Abu-Asab, M.; Shelhamer, J.H.; Kehrl, J.H. SARS-coronavirus open reading frame-9b suppresses innate immunity by targeting mitochondria and the MAVS/TRAF3/TRAF6 signalosome. J. Immunol. 2014, 193, 3080-3089. [CrossRef] [PubMed]

62. Woo, P.C.; Lau, S.K.; Huang, Y.; Yuen, K.Y. Coronavirus diversity, phylogeny and interspecies jumping. Exp. Biol. Med. 2009, 234, 1117-1127. [CrossRef] [PubMed]

63. Woo, P.C.; Lau, S.K.; Li, K.S.; Poon, R.W.; Wong, B.H.; Tsoi, H.W.; Yip, B.C.; Huang, Y.; Chan, K.H.; Yuen, K.Y. Molecular diversity of coronaviruses in bats. Virology 2006, 351, 180-187. [CrossRef]

64. Woo, P.C.; Wang, M.; Lau, S.K.; Xu, H.; Poon, R.W.; Guo, R.; Wong, B.H.; Gao, K.; Tsoi, H.W.; Huang, Y.; et al. Comparative analysis of twelve genomes of three novel group $2 \mathrm{c}$ and group $2 \mathrm{~d}$ coronaviruses reveals unique group and subgroup features. $J$. Virol. 2007, 81, 1574-1585. [CrossRef] [PubMed]

65. Woo, P.C.; Lau, S.K.; Lam, C.S.; Lau, C.C.; Tsang, A.K.; Lau, J.H.; Bai, R.; Teng, J.L.; Tsang, C.C.; Wang, M.; et al. Discovery of seven novel Mammalian and avian coronaviruses in the genus deltacoronavirus supports bat coronaviruses as the gene source of alphacoronavirus and betacoronavirus and avian coronaviruses as the gene source of gammacoronavirus and deltacoronavirus. J. Virol. 2012, 86, 3995-4008. [CrossRef]

66. Lau, S.K.P.; Wong, E.Y.M.; Tsang, C.C.; Ahmed, S.S.; Au-Yeung, R.K.H.; Yuen, K.Y.; Wernery, U.; Woo, P.C.Y. Discovery and Sequence Analysis of Four Deltacoronaviruses from Birds in the Middle East Reveal Interspecies Jumping with Recombination as a Potential Mechanism for Avian-to-Avian and Avian-to-Mammalian Transmission. J. Virol. 2018, 92, 15. [CrossRef]

67. Lau, S.K.; Poon, R.W.; Wong, B.H.; Wang, M.; Huang, Y.; Xu, H.; Guo, R.; Li, K.S.; Gao, K.; Chan, K.H.; et al. Coexistence of different genotypes in the same bat and serological characterization of Rousettus bat coronavirus HKU9 belonging to a novel Betacoronavirus subgroup. J. Virol. 2010, 84, 11385-11394. [CrossRef]

68. Woo, P.C.; Lau, S.K.; Tsang, C.C.; Lau, C.C.; Wong, P.C.; Chow, F.W.; Fong, J.Y.; Yuen, K.Y. Coronavirus HKU15 in respiratory tract of pigs and first discovery of coronavirus quasispecies in $5^{\prime}$-untranslated region. Emerg. Microbes Infect. 2017, 6, e53. [CrossRef] [PubMed]

69. De Groot, R.J.; Baker, S.C.; Baric, R.S.; Brown, C.S.; Drosten, C.; Enjuanes, L.; Fouchier, R.A.; Galiano, M.; Gorbalenya, A.E.; Memish, Z.A.; et al. Middle East respiratory syndrome coronavirus (MERS-CoV): Announcement of the Coronavirus Study Group. J. Virol. 2013, 87, 7790-7792. [CrossRef]

70. Zaki, A.M.; van Boheemen, S.; Bestebroer, T.M.; Osterhaus, A.D.; Fouchier, R.A. Isolation of a novel coronavirus from a man with pneumonia in Saudi Arabia. N. Engl. J. Med. 2012, 367, 1814-1820. [CrossRef]

71. Oh, M.D.; Park, W.B.; Park, S.W.; Choe, P.G.; Bang, J.H.; Song, K.H.; Kim, E.S.; Kim, H.B.; Kim, N.J. Middle East respiratory syndrome: What we learned from the 2015 outbreak in the Republic of Korea. Korean J. Intern. Med. 2018, 33, 233-246. [CrossRef]

72. Hui, D.S.; Perlman, S.; Zumla, A. Spread of MERS to South Korea and China. Lancet Respir. Med. 2015, 3, 509-510. [CrossRef]

73. Memish, Z.A.; Perlman, S.; Van Kerkhove, M.D.; Zumla, A. Middle East respiratory syndrome. Lancet 2020, $395,1063-1077$. [CrossRef] 
74. Alagaili, A.N.; Briese, T.; Mishra, N.; Kapoor, V.; Sameroff, S.C.; Burbelo, P.D.; de Wit, E.; Munster, V.J.; Hensley, L.E.; Zalmout, I.S.; et al. Middle East respiratory syndrome coronavirus infection in dromedary camels in Saudi Arabia. mBio 2014, 5, e00884-14. [CrossRef] [PubMed]

75. Reusken, C.B.; Ababneh, M.; Raj, V.S.; Meyer, B.; Eljarah, A.; Abutarbush, S.; Godeke, G.J.; Bestebroer, T.M.; Zutt, I.; Muller, M.A.; et al. Middle East Respiratory Syndrome coronavirus (MERS-CoV) serology in major livestock species in an affected region in Jordan, June to September 2013. Eurosurveilliance 2013, 18, 20662. [CrossRef] [PubMed]

76. Kandeil, A.; Gomaa, M.; Nageh, A.; Shehata, M.M.; Kayed, A.E.; Sabir, J.S.M.; Abiadh, A.; Jrijer, J.; Amr, Z.; Said, M.A.; et al. Middle East Respiratory Syndrome Coronavirus (MERS-CoV) in Dromedary Camels in Africa and Middle East. Viruses 2019, 11, 717. [CrossRef]

77. Conzade, R.; Grant, R.; Malik, M.R.; Elkholy, A.; Elhakim, M.; Samhouri, D.; Ben Embarek, P.K.; Van Kerkhove, M.D. Reported Direct and Indirect Contact with Dromedary Camels among Laboratory-Confirmed MERS-CoV Cases. Viruses 2018, 10, 425. [CrossRef]

78. Wernery, U.; El Rasoul, I.H.; Wong, E.Y.; Joseph, M.; Chen, Y.; Jose, S.; Tsang, A.K.; Patteril, N.A.; Chen, H.; Elizabeth, S.K.; et al. A phylogenetically distinct Middle East respiratory syndrome coronavirus detected in a dromedary calf from a closed dairy herd in Dubai with rising seroprevalence with age. Emerg. Microbes Infect. 2015, 4, e74. [CrossRef]

79. Adney, D.R.; Letko, M.; Ragan, I.K.; Scott, D.; van Doremalen, N.; Bowen, R.A.; Munster, V.J. Bactrian camels shed large quantities of Middle East respiratory syndrome coronavirus (MERS-CoV) after experimental infection. Emerg. Microbes Infect. 2019, 8 , 717-723. [CrossRef]

80. Lau, S.K.P.; Li, K.S.M.; Luk, H.K.H.; He, Z.; Teng, J.L.L.; Yuen, K.Y.; Wernery, U.; Woo, P.C.Y. Middle East Respiratory Syndrome Coronavirus Antibodies in Bactrian and Hybrid Camels from Dubai. mSphere 2020, 5, e00898-19. [CrossRef] [PubMed]

81. Woo, P.C.; Lau, S.K.; Li, K.S.; Tsang, A.K.; Yuen, K.Y. Genetic relatedness of the novel human group C betacoronavirus to Tylonycteris bat coronavirus HKU4 and Pipistrellus bat coronavirus HKU5. Emerg. Microbes Infect. 2012, 1, e35. [CrossRef]

82. Lau, S.K.; Li, K.S.; Tsang, A.K.; Lam, C.S.; Ahmed, S.; Chen, H.; Chan, K.H.; Woo, P.C.; Yuen, K.Y. Genetic characterization of Betacoronavirus lineage $C$ viruses in bats reveals marked sequence divergence in the spike protein of pipistrellus bat coronavirus HKU5 in Japanese pipistrelle: Implications for the origin of the novel Middle East respiratory syndrome coronavirus. J. Virol. 2013, 87, 8638-8650. [CrossRef]

83. Lau, S.K.P.; Zhang, L.; Luk, H.K.H.; Xiong, L.; Peng, X.; Li, K.S.M.; He, X.; Zhao, P.S.; Fan, R.Y.Y.; Wong, A.C.P.; et al. Receptor Usage of a Novel Bat Lineage C Betacoronavirus Reveals Evolution of Middle East Respiratory Syndrome-Related Coronavirus Spike Proteins for Human Dipeptidyl Peptidase 4 Binding. J. Infect. Dis. 2018, 218, 197-207. [CrossRef] [PubMed]

84. Corman, V.M.; Ithete, N.L.; Richards, L.R.; Schoeman, M.C.; Preiser, W.; Drosten, C.; Drexler, J.F. Rooting the phylogenetic tree of middle East respiratory syndrome coronavirus by characterization of a conspecific virus from an African bat. J. Virol. 2014, 88, 11297-11303. [CrossRef]

85. Anthony, S.J.; Gilardi, K.; Menachery, V.D.; Goldstein, T.; Ssebide, B.; Mbabazi, R.; Navarrete-Macias, I.; Liang, E.; Wells, H.; Hicks, A.; et al. Further Evidence for Bats as the Evolutionary Source of Middle East Respiratory Syndrome Coronavirus. mBio 2017, 8, e00373-17. [CrossRef]

86. Lau, S.K.P.; Luk, H.K.H.; Wong, A.C.P.; Fan, R.Y.Y.; Lam, C.S.F.; Li, K.S.M.; Ahmed, S.S.; Chow, F.W.N.; Cai, J.P.; Zhu, X.; et al. Identification of a Novel Betacoronavirus (Merbecovirus) in Amur Hedgehogs from China. Viruses 2019, 11, 980. [CrossRef] [PubMed]

87. Corman, V.M.; Kallies, R.; Philipps, H.; Gopner, G.; Muller, M.A.; Eckerle, I.; Brunink, S.; Drosten, C.; Drexler, J.F. Characterization of a novel betacoronavirus related to middle East respiratory syndrome coronavirus in European hedgehogs. J. Virol. 2014, 88, 717-724. [CrossRef] [PubMed]

88. Yang, L.; Wu, Z.; Ren, X.; Yang, F.; Zhang, J.; He, G.; Dong, J.; Sun, L.; Zhu, Y.; Zhang, S.; et al. MERS-related betacoronavirus in Vespertilio superans bats, China. Emerg. Infect. Dis. 2014, 20, 1260-1262. [CrossRef]

89. Moreno, A.; Lelli, D.; De Sabato, L.; Zaccaria, G.; Boni, A.; Sozzi, E.; Prosperi, A.; Lavazza, A.; Cella, E.; Castrucci, M.R.; et al. Detection and full genome characterization of two beta $\mathrm{CoV}$ viruses related to Middle East respiratory syndrome from bats in Italy $(14,1,2017)$. Virol. J. 2018, 15, 10. [CrossRef]

90. Menachery, V.D.; Mitchell, H.D.; Cockrell, A.S.; Gralinski, L.E.; Yount, B.L., Jr.; Graham, R.L.; McAnarney, E.T.; Douglas, M.G.; Scobey, T.; Beall, A.; et al. MERS-CoV Accessory ORFs Play Key Role for Infection and Pathogenesis. mBio 2017, 8, 00665-17. [CrossRef]

91. Siu, K.L.; Yeung, M.L.; Kok, K.H.; Yuen, K.S.; Kew, C.; Lui, P.Y.; Chan, C.P.; Tse, H.; Woo, P.C.; Yuen, K.Y.; et al. Middle east respiratory syndrome coronavirus 4a protein is a double-stranded RNA-binding protein that suppresses PACT-induced activation of RIG-I and MDA5 in the innate antiviral response. J. Virol. 2014, 88, 4866-4876. [CrossRef]

92. Rabouw, H.H.; Langereis, M.A.; Knaap, R.C.; Dalebout, T.J.; Canton, J.; Sola, I.; Enjuanes, L.; Bredenbeek, P.J.; Kikkert, M.; de Groot, R.J.; et al. Middle East Respiratory Coronavirus Accessory Protein 4a Inhibits PKR-Mediated Antiviral Stress Responses. PLoS Pathog. 2016, 12, e1005982. [CrossRef] [PubMed]

93. Yang, Y.; Ye, F.; Zhu, N.; Wang, W.; Deng, Y.; Zhao, Z.; Tan, W. Middle East respiratory syndrome coronavirus ORF4b protein inhibits type I interferon production through both cytoplasmic and nuclear targets. Sci. Rep. 2015, 5, 17554. [CrossRef]

94. Lee, J.Y.; Bae, S.; Myoung, J. Middle East respiratory syndrome coronavirus-encoded ORF8b strongly antagonizes IFN-beta promoter activation: Its implication for vaccine design. J. Microbiol. 2019, 57, 803-811. [CrossRef] 
95. Wong, L.R.; Ye, Z.W.; Lui, P.Y.; Zheng, X.; Yuan, S.; Zhu, L.; Fung, S.Y.; Yuen, K.S.; Siu, K.L.; Yeung, M.L.; et al. Middle East Respiratory Syndrome Coronavirus ORF8b Accessory Protein Suppresses Type I IFN Expression by Impeding HSP70-Dependent Activation of IRF3 Kinase IKKepsilon. J. Immunol. 2020, 205, 1564-1579. [CrossRef]

96. Wang, N.; Shi, X.; Jiang, L.; Zhang, S.; Wang, D.; Tong, P.; Guo, D.; Fu, L.; Cui, Y.; Liu, X.; et al. Structure of MERS-CoV spike receptor-binding domain complexed with human receptor DPP4. Cell Res 2013, 23, 986-993. [CrossRef] [PubMed]

97. Wang, Q.; Qi, J.; Yuan, Y.; Xuan, Y.; Han, P.; Wan, Y.; Ji, W.; Li, Y.; Wu, Y.; Wang, J.; et al. Bat origins of MERS-CoV supported by bat coronavirus HKU4 usage of human receptor CD26. Cell Host Microb. 2014, 16, 328-337. [CrossRef]

98. Yang, Y.; Du, L.; Liu, C.; Wang, L.; Ma, C.; Tang, J.; Baric, R.S.; Jiang, S.; Li, F. Receptor usage and cell entry of bat coronavirus HKU4 provide insight into bat-to-human transmission of MERS coronavirus. Proc. Natl. Acad. Sci. USA 2014, 111, 12516-12521. [CrossRef]

99. Lau, S.K.P.; Fan, R.Y.Y.; Zhu, L.; Li, K.S.M.; Wong, A.C.P.; Luk, H.K.H.; Wong, E.Y.M.; Lam, C.S.F.; Lo, G.C.S.; Fung, J.; et al. Isolation of MERS-related coronavirus from lesser bamboo bats that uses DPP4 and infects human-DPP4-transgenic mice. Nat. Commun. 2021, 12, 216. [CrossRef] [PubMed]

100. Lau, S.K.; Woo, P.C.; Li, K.S.; Huang, Y.; Wang, M.; Lam, C.S.; Xu, H.; Guo, R.; Chan, K.H.; Zheng, B.J.; et al. Complete genome sequence of bat coronavirus HKU2 from Chinese horseshoe bats revealed a much smaller spike gene with a different evolutionary lineage from the rest of the genome. Virology 2007, 367, 428-439. [CrossRef] [PubMed]

101. Falcon, A.; Vazquez-Moron, S.; Casas, I.; Aznar, C.; Ruiz, G.; Pozo, F.; Perez-Brena, P.; Juste, J.; Ibanez, C.; Garin, I.; et al. Detection of alpha and betacoronaviruses in multiple Iberian bat species. Arch. Virol. 2011, 156, 1883-1890. [CrossRef] [PubMed]

102. August, T.A.; Mathews, F.; Nunn, M.A. Alphacoronavirus detected in bats in the United Kingdom. Vector Borne Zoonotic Dis. 2012, 12, 530-533. [CrossRef]

103. Bourgarel, M.; Pfukenyi, D.M.; Boue, V.; Talignani, L.; Chiweshe, N.; Diop, F.; Caron, A.; Matope, G.; Misse, D.; Liegeois, F. Circulation of Alphacoronavirus, Betacoronavirus and Paramyxovirus in Hipposideros bat species in Zimbabwe. Infect. Genet. Evol. 2018, 58, 253-257. [CrossRef]

104. Lazov, C.M.; Chriel, M.; Baagoe, H.J.; Fjederholt, E.; Deng, Y.; Kooi, E.A.; Belsham, G.J.; Botner, A.; Rasmussen, T.B. Detection and Characterization of Distinct Alphacoronaviruses in Five Different Bat Species in Denmark. Viruses 2018, 10, 485. [CrossRef]

105. Wu, Z.; Yang, L.; Ren, X.; He, G.; Zhang, J.; Yang, J.; Qian, Z.; Dong, J.; Sun, L.; Zhu, Y.; et al. Deciphering the bat virome catalog to better understand the ecological diversity of bat viruses and the bat origin of emerging infectious diseases. ISME J. 2016, 10, 609-620. [CrossRef]

106. Wacharapluesadee, S.; Duengkae, P.; Rodpan, A.; Kaewpom, T.; Maneeorn, P.; Kanchanasaka, B.; Yingsakmongkon, S.; Sittidetboripat, N.; Chareesaen, C.; Khlangsap, N.; et al. Diversity of coronavirus in bats from Eastern Thailand. Virol. J. 2015, 12, 57. [CrossRef]

107. Zhou, P.; Fan, H.; Lan, T.; Yang, X.L.; Shi, W.F.; Zhang, W.; Zhu, Y.; Zhang, Y.W.; Xie, Q.M.; Mani, S.; et al. Fatal swine acute diarrhoea syndrome caused by an HKU2-related coronavirus of bat origin. Nature 2018, 556, 255-258. [CrossRef]

108. Wang, W.; Lin, X.D.; Guo, W.P.; Zhou, R.H.; Wang, M.R.; Wang, C.Q.; Ge, S.; Mei, S.H.; Li, M.H.; Shi, M.; et al. Discovery, diversity and evolution of novel coronaviruses sampled from rodents in China. Virology 2015, 474, 19-27. [CrossRef]

109. Wang, W.; Lin, X.D.; Liao, Y.; Guan, X.Q.; Guo, W.P.; Xing, J.G.; Holmes, E.C.; Zhang, Y.Z. Discovery of a Highly Divergent Coronavirus in the Asian House Shrew from China Illuminates the Origin of the Alphacoronaviruses. J. Virol. 2017, 91, e00764-17. [CrossRef] [PubMed]

110. Gong, L.; Li, J.; Zhou, Q.; Xu, Z.; Chen, L.; Zhang, Y.; Xue, C.; Wen, Z.; Cao, Y. A New Bat-HKU2-like Coronavirus in Swine, China, 2017. Emerg. Infect. Dis. 2017, 23, 1607-1609. [CrossRef] [PubMed]

111. Pan, Y.; Tian, X.; Qin, P.; Wang, B.; Zhao, P.; Yang, Y.L.; Wang, L.; Wang, D.; Song, Y.; Zhang, X.; et al. Discovery of a novel swine enteric alphacoronavirus (SeACoV) in southern China. Vet. Microbiol. 2017, 211, 15-21. [CrossRef] [PubMed]

112. Zhou, L.; Sun, Y.; Lan, T.; Wu, R.; Chen, J.; Wu, Z.; Xie, Q.; Zhang, X.; Ma, J. Retrospective detection and phylogenetic analysis of swine acute diarrhoea syndrome coronavirus in pigs in southern China. Transbound Emerg. Dis. 2019, 66, 687-695. [CrossRef] [PubMed]

113. Yang, Y.L.; Yu, J.Q.; Huang, Y.W. Swine enteric alphacoronavirus (swine acute diarrhea syndrome coronavirus): An update three years after its discovery. Virus Res 2020, 285, 198024. [CrossRef] [PubMed]

114. Zhou, L.; Li, Q.N.; Su, J.N.; Chen, G.H.; Wu, Z.X.; Luo, Y.; Wu, R.T.; Sun, Y.; Lan, T.; Ma, J.Y. The re-emerging of SADS-CoV infection in pig herds in Southern China. Transbound Emerg. Dis. 2019, 66, 2180-2183. [CrossRef] [PubMed]

115. Lau, S.K.; Wernery, R.; Wong, E.Y.; Joseph, S.; Tsang, A.K.; Patteril, N.A.; Elizabeth, S.K.; Chan, K.H.; Muhammed, R.; Kinne, J.; et al. Polyphyletic origin of MERS coronaviruses and isolation of a novel clade A strain from dromedary camels in the United Arab Emirates. Emerg. Microbes Infect. 2016, 5, e128. [CrossRef]

116. Zhu, N.; Zhang, D.; Wang, W.; Li, X.; Yang, B.; Song, J.; Zhao, X.; Huang, B.; Shi, W.; Lu, R.; et al. A Novel Coronavirus from Patients with Pneumonia in China, 2019. N. Engl. J. Med. 2020, 382, 727-733. [CrossRef]

117. Polack, F.P.; Thomas, S.J.; Kitchin, N.; Absalon, J.; Gurtman, A.; Lockhart, S.; Perez, J.L.; Perez Marc, G.; Moreira, E.D.; Zerbini, C.; et al. Safety and Efficacy of the BNT162b2 mRNA COVID-19 Vaccine. N. Engl. J. Med. 2020, 383, 2603-2615. [CrossRef] [PubMed]

118. Baden, L.R.; El Sahly, H.M.; Essink, B.; Kotloff, K.; Frey, S.; Novak, R.; Diemert, D.; Spector, S.A.; Rouphael, N.; Creech, C.B.; et al Efficacy and Safety of the mRNA-1273 SARS-CoV-2 Vaccine. N. Engl. J. Med. 2021, 384, 403-416. [CrossRef] 
119. Falsey, A.R.; Sobieszczyk, M.E.; Hirsch, I.; Sproule, S.; Robb, M.L.; Corey, L.; Neuzil, K.M.; Hahn, W.; Hunt, J.; Mulligan, M.J.; et al. Phase 3 Safety and Efficacy of AZD1222 (ChAdOx1 nCoV-19) COVID-19 Vaccine. N. Engl. J. Med. 2021. [CrossRef]

120. Lau, S.K.P.; Luk, H.K.H.; Wong, A.C.P.; Li, K.S.M.; Zhu, L.; He, Z.; Fung, J.; Chan, T.T.Y.; Fung, K.S.C.; Woo, P.C.Y. Possible Bat Origin of Severe Acute Respiratory Syndrome Coronavirus 2. Emerg. Infect. Dis. 2020, 26, 1542-1547. [CrossRef]

121. Wu, J.T.; Leung, K.; Lam, T.T.Y.; Ni, M.Y.; Wong, C.K.H.; Peiris, J.S.M.; Leung, G.M. Nowcasting epidemics of novel pathogens: Lessons from COVID-19. Nat. Med. 2021, 27, 388-395. [CrossRef]

122. Apolone, G.; Montomoli, E.; Manenti, A.; Boeri, M.; Sabia, F.; Hyseni, I.; Mazzini, L.; Martinuzzi, D.; Cantone, L.; Milanese, G.; et al. Unexpected detection of SARS-CoV-2 antibodies in the prepandemic period in Italy. Tumori 2020, 107, 446-451. [CrossRef]

123. Coronaviridae Study Group of the International Committee on Taxonomy of Viruses. The species severe acute respiratory syndrome-related coronavirus: Classifying 2019-nCoV and naming it SARS-CoV-2. Nat. Microbiol. 2020, 5, 536-544. [CrossRef]

124. Zhou, P.; Shi, Z.L. SARS-CoV-2 spillover events. Science 2021, 371, 120-122. [CrossRef] [PubMed]

125. Badr, H.S.; Du, H.R.; Marshall, M.; Dong, E.S.; Squire, M.M.; Gardner, L.M. Association between mobility patterns and COVID-19 transmission in the USA: A mathematical modelling study. Lancet Infect. Dis. 2020, 20, 1247-1254. [CrossRef]

126. Liu, Y.; Gayle, A.A.; Wilder-Smith, A.; Rocklov, J. The reproductive number of COVID-19 is higher compared to SARS coronavirus. J. Travel Med. 2020, 27, taaa021. [CrossRef] [PubMed]

127. Adam, D.C.; Wu, P.; Wong, J.Y.; Lau, E.H.Y.; Tsang, T.K.; Cauchemez, S.; Leung, G.M.; Cowling, B.J. Clustering and superspreading potential of SARS-CoV-2 infections in Hong Kong. Nat. Med. 2020, 26, 1714-1719. [CrossRef]

128. Bian, L.; Gao, Q.; Gao, F.; Wang, Q.; He, Q.; Wu, X.; Mao, Q.; Xu, M.; Liang, Z. Impact of the Delta variant on vaccine efficacy and response strategies. Expert Rev. Vac. 2021. [CrossRef]

129. Lazarevic, I.; Pravica, V.; Miljanovic, D.; Cupic, M. Immune Evasion of SARS-CoV-2 Emerging Variants: What Have We Learnt So Far? Viruses 2021, 13, 1192. [CrossRef] [PubMed]

130. Edara, V.V.; Lai, L.; Sahoo, M.K.; Floyd, K.; Sibai, M.; Solis, D.; Flowers, M.W.; Hussaini, L.; Ciric, C.R.; Bechnack, S.; et al. Infection and vaccine-induced neutralizing antibody responses to the SARS-CoV-2 B.1.617.1 variant. bioRxiv 2021. [CrossRef]

131. Liu, C.; Ginn, H.M.; Dejnirattisai, W.; Supasa, P.; Wang, B.; Tuekprakhon, A.; Nutalai, R.; Zhou, D.; Mentzer, A.J.; Zhao, Y.; et al. Reduced neutralization of SARS-CoV-2 B.1.617 by vaccine and convalescent serum. Cell 2021, 184, 4220-4236.e13. [CrossRef]

132. Haydon, D.T.; Cleaveland, S.; Taylor, L.H.; Laurenson, M.K. Identifying reservoirs of infection: A conceptual and practical challenge. Emerg. Infect. Dis. 2002, 8, 1468-1473. [CrossRef] [PubMed]

133. Lau, S.K.; Woo, P.C.; Yip, C.C.; Tse, H.; Tsoi, H.W.; Cheng, V.C.; Lee, P.; Tang, B.S.; Cheung, C.H.; Lee, R.A.; et al. Coronavirus HKU1 and other coronavirus infections in Hong Kong. J. Clin. Microbiol. 2006, 44, 2063-2071. [CrossRef]

134. Woo, P.C.; Lau, S.K.; Yip, C.C.; Huang, Y.; Tsoi, H.W.; Chan, K.H.; Yuen, K.Y. Comparative analysis of 22 coronavirus HKU1 genomes reveals a novel genotype and evidence of natural recombination in coronavirus HKU1. J. Virol. 2006, 80, 7136-7145. [CrossRef] [PubMed]

135. Lau, S.K.; Lee, P.; Tsang, A.K.; Yip, C.C.; Tse, H.; Lee, R.A.; So, L.Y.; Lau, Y.L.; Chan, K.H.; Woo, P.C.; et al. Molecular epidemiology of human coronavirus OC43 reveals evolution of different genotypes over time and recent emergence of a novel genotype due to natural recombination. J. Virol. 2011, 85, 11325-11337. [CrossRef]

136. Komabayashi, K.; Seto, J.; Matoba, Y.; Aoki, Y.; Tanaka, S.; Ikeda, T.; Matsuzaki, Y.; Itagaki, T.; Mizuta, K. Seasonality of Human Coronavirus OC43, NL63, HKU1, and 229E Infection in Yamagata, Japan, 2010-2019. Jpn. J. Infect. Dis. 2020, 73, 394-397. [CrossRef]

137. Lau, S.K.P.; Lung, D.C.; Wong, E.Y.M.; Aw-Yong, K.L.; Wong, A.C.P.; Luk, H.K.H.; Li, K.S.M.; Fung, J.; Chan, T.T.Y.; Tang, J.Y.M.; et al. Molecular Evolution of Human Coronavirus 229E in Hong Kong and a Fatal COVID-19 Case Involving Coinfection with a Novel Human Coronavirus 229E Genogroup. mSphere 2021, 6, e00819-20. [CrossRef]

138. Gollakner, R.; Capua, I. Is COVID-19 the first pandemic that evolves into a panzootic? Vet. Ital. 2020, 56, 7-8. [CrossRef]

139. Oude Munnink, B.B.; Sikkema, R.S.; Nieuwenhuijse, D.F.; Molenaar, R.J.; Munger, E.; Molenkamp, R.; van der Spek, A.; Tolsma, P.; Rietveld, A.; Brouwer, M.; et al. Transmission of SARS-CoV-2 on mink farms between humans and mink and back to humans. Science 2021, 371, 172-177. [CrossRef]

140. Sharun, K.; Tiwari, R.; Natesan, S.; Dhama, K. SARS-CoV-2 infection in farmed minks, associated zoonotic concerns, and importance of the One Health approach during the ongoing COVID-19 pandemic. Vet. Q. 2021, 41, 50-60. [CrossRef]

141. Sharun, K.; Dhama, K.; Pawde, A.M.; Gortazar, C.; Tiwari, R.; Bonilla-Aldana, D.K.; Rodriguez-Morales, A.J.; de la Fuente, J.; Michalak, I.; Attia, Y.A. SARS-CoV-2 in animals: Potential for unknown reservoir hosts and public health implications. Vet. $Q$. 2021, 41, 181-201. [CrossRef] [PubMed]

142. Huang, C.; Wang, Y.; Li, X.; Ren, L.; Zhao, J.; Hu, Y.; Zhang, L.; Fan, G.; Xu, J.; Gu, X.; et al. Clinical features of patients infected with 2019 novel coronavirus in Wuhan, China. Lancet 2020, 395, 497-506. [CrossRef]

143. Lau, S.K.P.; Wong, A.C.P.; Luk, H.K.H.; Li, K.S.M.; Fung, J.; He, Z.; Cheng, F.K.K.; Chan, T.T.Y.; Chu, S.; Aw-Yong, K.L.; et al Differential Tropism of SARS-CoV and SARS-CoV-2 in Bat Cells. Emerg. Infect. Dis. 2020, 26, 2961-2965. [CrossRef] [PubMed]

144. Bao, L.; Deng, W.; Huang, B.; Gao, H.; Liu, J.; Ren, L.; Wei, Q.; Yu, P.; Xu, Y.; Qi, F.; et al. The pathogenicity of SARS-CoV-2 in hACE2 transgenic mice. Nature 2020, 583, 830-833. [CrossRef]

145. Chan, J.F.; Zhang, A.J.; Yuan, S.; Poon, V.K.; Chan, C.C.; Lee, A.C.; Chan, W.M.; Fan, Z.; Tsoi, H.W.; Wen, L.; et al. Simulation of the clinical and pathological manifestations of Coronavirus Disease 2019 (COVID-19) in golden Syrian hamster model: Implications for disease pathogenesis and transmissibility. Clin. Infect. Dis. 2020, 71, 2428-2446. [CrossRef] 
146. Chu, H.; Chan, J.F.-W.; Yuen, T.T.-T.; Shuai, H.; Yuan, S.; Wang, Y.; Hu, B.; Yip, C.C.-Y.; Tsang, J.O.-L.; Huang, X.; et al. Comparative tropism, replication kinetics, and cell damage profiling of SARS-CoV-2 and SARS-CoV with implications for clinical manifestations, transmissibility, and laboratory studies of COVID-19: An observational study. Lancet Microbe 2020, 1, e14-e23. [CrossRef]

147. Munster, V.J.; Feldmann, F.; Williamson, B.N.; van Doremalen, N.; Perez-Perez, L.; Schulz, J.; Meade-White, K.; Okumura, A.; Callison, J.; Brumbaugh, B.; et al. Respiratory disease in rhesus macaques inoculated with SARS-CoV-2. Nature 2020, 585, 268-272. [CrossRef]

148. Letko, M.; Marzi, A.; Munster, V. Functional assessment of cell entry and receptor usage for SARS-CoV-2 and other lineage B betacoronaviruses. Nat. Microbiol. 2020, 5, 562-569. [CrossRef] [PubMed]

149. Ou, X.; Liu, Y.; Lei, X.; Li, P.; Mi, D.; Ren, L.; Guo, L.; Guo, R.; Chen, T.; Hu, J.; et al. Characterization of spike glycoprotein of SARS-CoV-2 on virus entry and its immune cross-reactivity with SARS-CoV. Nat. Commun. 2020, 11, 1620. [CrossRef]

150. Shang, J.; Wan, Y.; Luo, C.; Ye, G.; Geng, Q.; Auerbach, A.; Li, F. Cell entry mechanisms of SARS-CoV-2. Proc. Natl. Acad. Sci. USA 2020, 117, 11727-11734. [CrossRef]

151. Shang, J.; Ye, G.; Shi, K.; Wan, Y.; Luo, C.; Aihara, H.; Geng, Q.; Auerbach, A.; Li, F. Structural basis of receptor recognition by SARS-CoV-2. Nature 2020, 581, 221-224. [CrossRef] [PubMed]

152. Walls, A.C.; Park, Y.J.; Tortorici, M.A.; Wall, A.; McGuire, A.T.; Veesler, D. Structure, Function, and Antigenicity of the SARS-CoV-2 Spike Glycoprotein. Cell 2020, 181, 281-292.e286. [CrossRef]

153. Lam, T.T.; Jia, N.; Zhang, Y.W.; Shum, M.H.; Jiang, J.F.; Zhu, H.C.; Tong, Y.G.; Shi, Y.X.; Ni, X.B.; Liao, Y.S.; et al. Identifying SARS-CoV-2-related coronaviruses in Malayan pangolins. Nature 2020, 583, 282-285. [CrossRef] [PubMed]

154. Xiao, K.; Zhai, J.; Feng, Y.; Zhou, N.; Zhang, X.; Zou, J.J.; Li, N.; Guo, Y.; Li, X.; Shen, X.; et al. Isolation of SARS-CoV-2-related coronavirus from Malayan pangolins. Nature 2020, 583, 286-289. [CrossRef] [PubMed]

155. Sarah, T.; Khamsing, V.; Eduard Baquero, S.; Sandie, M.; Max, B.; Béatrice, R.; Bounsavane, D.; Yasaman, K.; Delphine, C.; Daosavanh, S.; et al. Coronaviruses with a SARS-CoV-2-like receptor-binding domain allowing ACE2-mediated entry into human cells isolated from bats of Indochinese peninsula. Nat. Portf. 2021. [CrossRef]

156. Cheng, Y.W.; Chao, T.L.; Li, C.L.; Chiu, M.F.; Kao, H.C.; Wang, S.H.; Pang, Y.H.; Lin, C.H.; Tsai, Y.M.; Lee, W.H.; et al. Furin Inhibitors Block SARS-CoV-2 Spike Protein Cleavage to Suppress Virus Production and Cytopathic Effects. Cell. Rep. 2020, 33, 108254. [CrossRef]

157. Lau, S.Y.; Wang, P.; Mok, B.W.; Zhang, A.J.; Chu, H.; Lee, A.C.; Deng, S.; Chen, P.; Chan, K.H.; Song, W.; et al. Attenuated SARS-CoV-2 variants with deletions at the S1/S2 junction. Emerg. Microbes Infect. 2020, 9, 837-842. [CrossRef] [PubMed]

158. Johnson, B.A.; Xie, X.; Bailey, A.L.; Kalveram, B.; Lokugamage, K.G.; Muruato, A.; Zou, J.; Zhang, X.; Juelich, T.; Smith, J.K.; et al. Loss of furin cleavage site attenuates SARS-CoV-2 pathogenesis. Nature 2021, 591, 293-299. [CrossRef] [PubMed]

159. Zhou, P.; Yang, X.L.; Wang, X.G.; Hu, B.; Zhang, L.; Zhang, W.; Si, H.R.; Zhu, Y.; Li, B.; Huang, C.L.; et al. A pneumonia outbreak associated with a new coronavirus of probable bat origin. Nature 2020, 579, 270-273. [CrossRef]

160. Coutard, B.; Valle, C.; de Lamballerie, X.; Canard, B.; Seidah, N.G.; Decroly, E. The spike glycoprotein of the new coronavirus 2019-nCoV contains a furin-like cleavage site absent in CoV of the same clade. Antiviral Res. 2020, 176, 104742. [CrossRef] [PubMed]

161. Wacharapluesadee, S.; Tan, C.W.; Maneeorn, P.; Duengkae, P.; Zhu, F.; Joyjinda, Y.; Kaewpom, T.; Chia, W.N.; Ampoot, W.; Lim, B.L.; et al. Evidence for SARS-CoV-2 related coronaviruses circulating in bats and pangolins in Southeast Asia. Nat. Commun. 2021, 12, 1430. [CrossRef] [PubMed]

162. Zhou, H.; Chen, X.; Hu, T.; Li, J.; Song, H.; Liu, Y.; Wang, P.; Liu, D.; Yang, J.; Holmes, E.C.; et al. A Novel Bat Coronavirus Closely Related to SARS-CoV-2 Contains Natural Insertions at the S1/S2 Cleavage Site of the Spike Protein. Curr. Biol. 2020, 30, 2196-2203.e3. [CrossRef] [PubMed]

163. Murakami, S.; Kitamura, T.; Suzuki, J.; Sato, R.; Aoi, T.; Fujii, M.; Matsugo, H.; Kamiki, H.; Ishida, H.; Takenaka-Uema, A.; et al. Detection and Characterization of Bat Sarbecovirus Phylogenetically Related to SARS-CoV-2, Japan. Emerg. Infect. Dis. 2020, 26, 3025-3029. [CrossRef]

164. Cui, J.; Li, F.; Shi, Z.L. Origin and evolution of pathogenic coronaviruses. Nat. Rev. Microbiol. 2018, 17, 181-192. [CrossRef] [PubMed]

165. Lau, S.K.P.; Fan, R.Y.Y.; Luk, H.K.H.; Zhu, L.; Fung, J.; Li, K.S.M.; Wong, E.Y.M.; Ahmed, S.S.; Chan, J.F.W.; Kok, R.K.H.; et al. Replication of MERS and SARS coronaviruses in bat cells offers insights to their ancestral origins. Emerg. Microbes Infect. 2018, 7, 209. [CrossRef] [PubMed]

166. Lau, S.K.P.; Wong, A.C.P.; Lau, T.C.K.; Woo, P.C.Y. Molecular Evolution of MERS Coronavirus: Dromedaries as a Recent Intermediate Host or Long-Time Animal Reservoir? Int. J. Mol. Sci. 2017, 18, 2138. [CrossRef] [PubMed]

167. Relman, D.A. Opinion: To stop the next pandemic, we need to unravel the origins of COVID-19. Proc. Natl. Acad. Sci. USA 2020, 117, 29246-29248. [CrossRef]

168. Edwards, C.E.; Yount, B.L.; Graham, R.L.; Leist, S.R.; Hou, Y.J.; Dinnon, K.H., 3rd; Sims, A.C.; Swanstrom, J.; Gully, K.; Scobey, T.D.; et al. Swine acute diarrhea syndrome coronavirus replication in primary human cells reveals potential susceptibility to infection. Proc. Natl. Acad. Sci. USA 2020, 117, 26915-26925. [CrossRef] [PubMed] 